\title{
REVIEW
}

\section{ECOLOGICAL, EVOLUTIONARY, AND SYSTEMATIC SIGNIFICANCE OF DIATOM LIFE HISTORIES ${ }^{1}$}

\author{
Mark B. Edlund and Eugene F. Stoermer
}

Center for Great Lakes and Aquatic Sciences, University of Michigan, 2200 Bonisteel Boulevard, Ann Arbor, Michigan 48109-2099

". . . we cannot understand the variation pattern within a group without a full knowledge of the reproductive biology of the populations which make it up." (G. L. Stebbins:359)

In spite of high species diversity and many years of study, most diatom life history strategies remain unknown. Floristics, taxonomy, and applied studies continue to dominate scientific efforts on diatoms; however, as Stebbins implied, it is difficult to pursue these ventures without an understanding of diatom reproductive biology. Recent research has added significantly to classic literature and has further expanded understanding of both the diversity of sexual behavior and the importance of life history strategies to ecology, evolution, taxonomy, and systematics of diatoms. Since the turn of the century, when reduction division was first convincingly demonstrated during gametogenesis in Rhopalodia (Klebahn 1896) and Surirella (Karsten 1912), it has been accepted that most diatoms have a diplontic life history (van den Hoek et al. 1995). Before and since that time, a great deal of work has been directed toward description and classification of diatom life histories (reviewed by Klebahn 1896, Geitler 1932, 1973, 1984, Fritsch 1935, Drebes 1977, Round et al. 1990, Hori 1993, Mann 1993, Roschin 1994), whereas far less effort has been directed at the ecologic and systematic implications of diatom life histories. The purpose of this review is not to reiterate or classify all the reported types of sexual reproduction in diatoms, but to provide current perspectives relating diatom life history strategies to systematic, ecologic, and evolutionary issues.

\section{A Review of the Diatom Life History}

Diatoms spend the majority of their diplontic life history going through mitotic asexual divisions. However, vegetative cellular growth is constrained by the bipartite opaline silica cell wall (frustule), one half (valve) being slightly larger (the epivalve) and its associated girdle elements (cingulum) overlapping the second slightly smaller valve's (the hypovalve) cingulum. Because of this cell wall arrangement, a diatom going through mitotic division produces two sibling cells; one sibling cell is identical in size to the parent cell and the second progeny is

\footnotetext{
${ }^{1}$ Received 19 April 1997. Accepted 25 August 1997.

2Author for reprint requests; e-mail mbedlund@umich.edu.
}

slightly smaller. This size diminution process was described over a century ago (MacDonald 1869, Pfitzer $1869,1871)$ and predicts that most mitotically dividing diatom populations will decrease in mean size and increase in standard deviation in individual cell dimensions (length, diameter) over time. The decrease in size is also accompanied by reduction in valve outline complexity (Geitler 1932, Stoermer and Ladewski 1982). Although some taxa have been shown to possess both physiologic and morphologic modifications to overcome size diminution (e.g. von Stosch 1965, Round 1972, Drebes 1977, Gallagher 1983 ), in most species size restoration occurs only through sexual reproduction. Contrary to most other algal groups, sexuality is the means of size restoration for diatoms and is not normally a factor in dormancy or dispersal (see Hargraves and French 1983, Pérez-Martínez et al. 1992, Waite and Harrison 1992, Jewson et al. 1993 for exceptions).

Sexual reproduction in diatoms can occur only after two general conditions have been met. First, cells must reach a minimum size range, typically $30-$ $40 \%$ of their maximum size. This size is known as their first cardinal point (Geitler 1932) and is defined as the size at which cells can be induced to become gametangia. The second factor that must be met to initiate sexuality is presence of the correct environmental conditions. These may include combinations of temperature, light, nutrients, trace metals, organic growth factors, and osmolarity (reviewed in Schmid 1995). Other investigators have suggested additional factors which may also be important in sexual induction. Vaulot and Chisholm (1987) and Armbrust et al. (1990) suggested that cell cycle phase may control sexual induction because spermatogenesis in Thalassiosira weissflogii (Grunow) G. A. Fryxell and Hasle was initiated only by cells in early $G_{1}$ phase of the cell cycle. In natural populations, gametogenesis was initiated only in cells that had experienced a check in their growth to hold them at this phase of their cell cycle (Jewson 1992a, b, Jewson et al. 1993). Some evidence for hormonal induction or control of sexuality has also been presented. In culture studies on Rhabdonema, gametogenesis would not occur unless male and female clones were cultured together (Rozumek 1968). In both centric (Drebes 1974) and many pennate taxa (Roschin 1994), dioecious reproduction or mating types are an important, yet poorly understood, factor in sexual induction. With successful induction, 

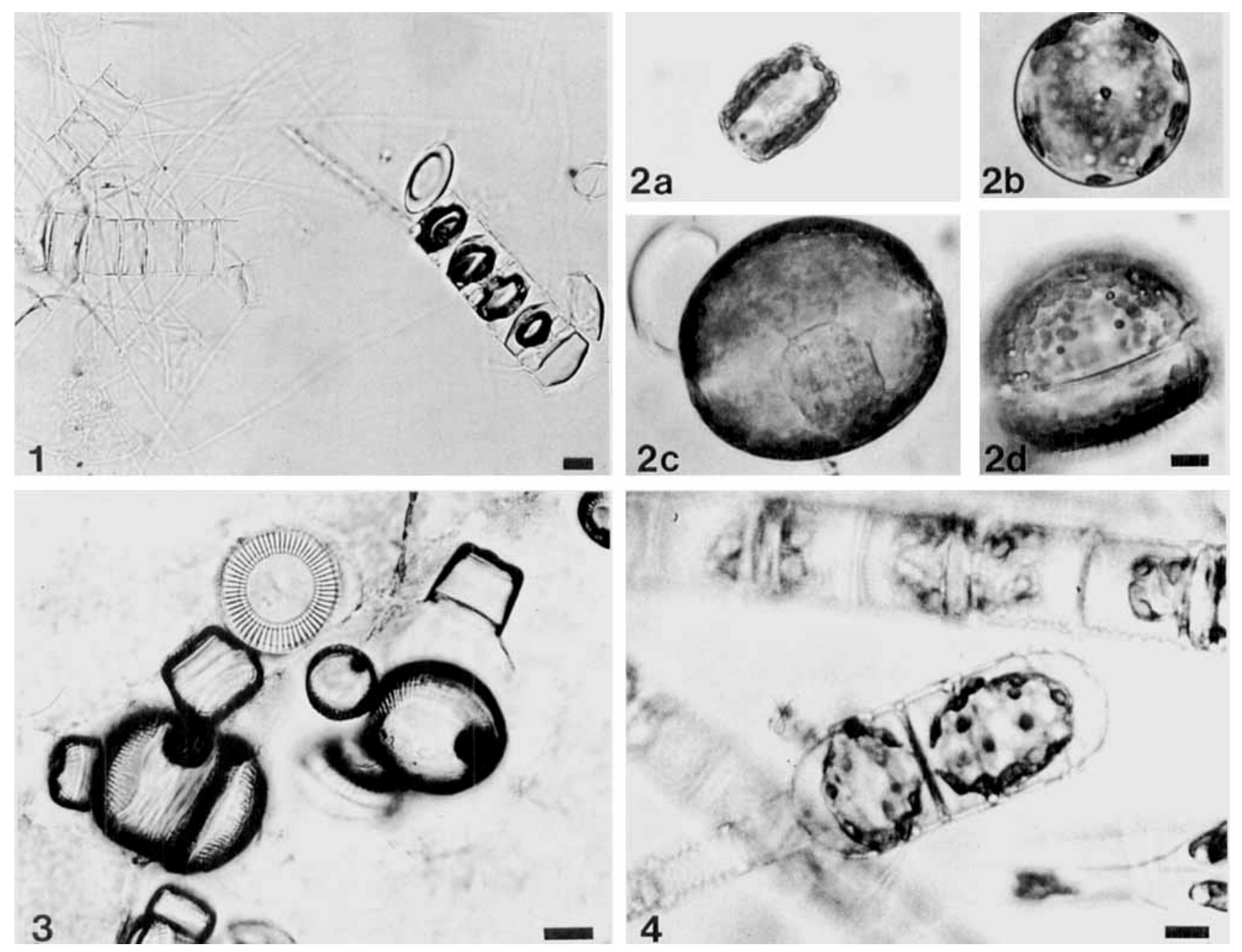

FICS. 1-4. Life history features of centric diatoms. Scale bars are approximately $10 \mu \mathrm{m}$. FiG. 1. Resting spores (right) and vegetative valves (left) of Chaetoceros elmorei C. S. Boyer, Devil's Lake, North Dakota. Fic. 2. Oogamous reproduction in cultured Stephanodiscus niagarae. a) Size of gametangial cells. b) Free auxospore. c) Silicified initial cell; auxospore membrane (upper left) has been cast off. d) Second division of initial cell produces first large vegetative cell. FIG. 3. Burn mount of oogamous reproduction in cultured Cyclotella gamma Sovereign. Note size and morphologic differences between vegetative and initial valves (culture courtesy of D. B. Czarnecki). FIG. 4. An initial cell of Aulacoseira baicalensis from Lake Baikal, Russia, has undergone the first mitotic division following sexual reproduction (photo courtesy of C. M. Taylor).

sexual reproduction can proceed. After sexual reproduction, size restoration is achieved, and diatoms achieve their second cardinal point when a cell line representing the largest size a taxon can attain is formed (Geitler 1932).

The three major groups of diatoms have evolved two very different approaches to sexual reproduction. Automictic and apomictic strategies (self-fertilization) exist but appear to be modifications of the more common types of sexuality. All members of the Coscinodiscophyceae (centric diatoms) that have been studied utilize oogamy (Figs. 2-4, 11). One or two large, nonmotile oogonia are produced per mother cell, whereas sperm cells are small, nonsiliceous, and motile by a single anterior pleuronematic flagellum with a $9+0$ microtubule construction. Members of the Fragilariophyceae and the Bacillariophyceae (the araphid and biraphid diatoms respectively) reproduce via isogamy or behavioral anisogamy (Figs. 6-10, 13). Diploid vegetative cells initiate sexual pairing via contact and/or production of mucilage envelopes or copulation tubes. Meiosis results in production of one or two gametes per parental gametangium. Gametes are morphologically identical but may exhibit behavioral differences during gametic exchange and fertilization in some taxa.

A notable exception to this dichotomy in sexuality occurs in Rhabdonema, an araphid pennate that has a unique form of anisogamy, which is often termed modified oogamy and implied to be transitional between oogamy and isogamy (Fig. 12). Rhabdonema produces two small, nonflagellate amoeboid male "spermatia" per spermatogonium which fertilize one or two large "oogonia" on a separate female filament (von Stosch 1958). Eggs are produced sim- 

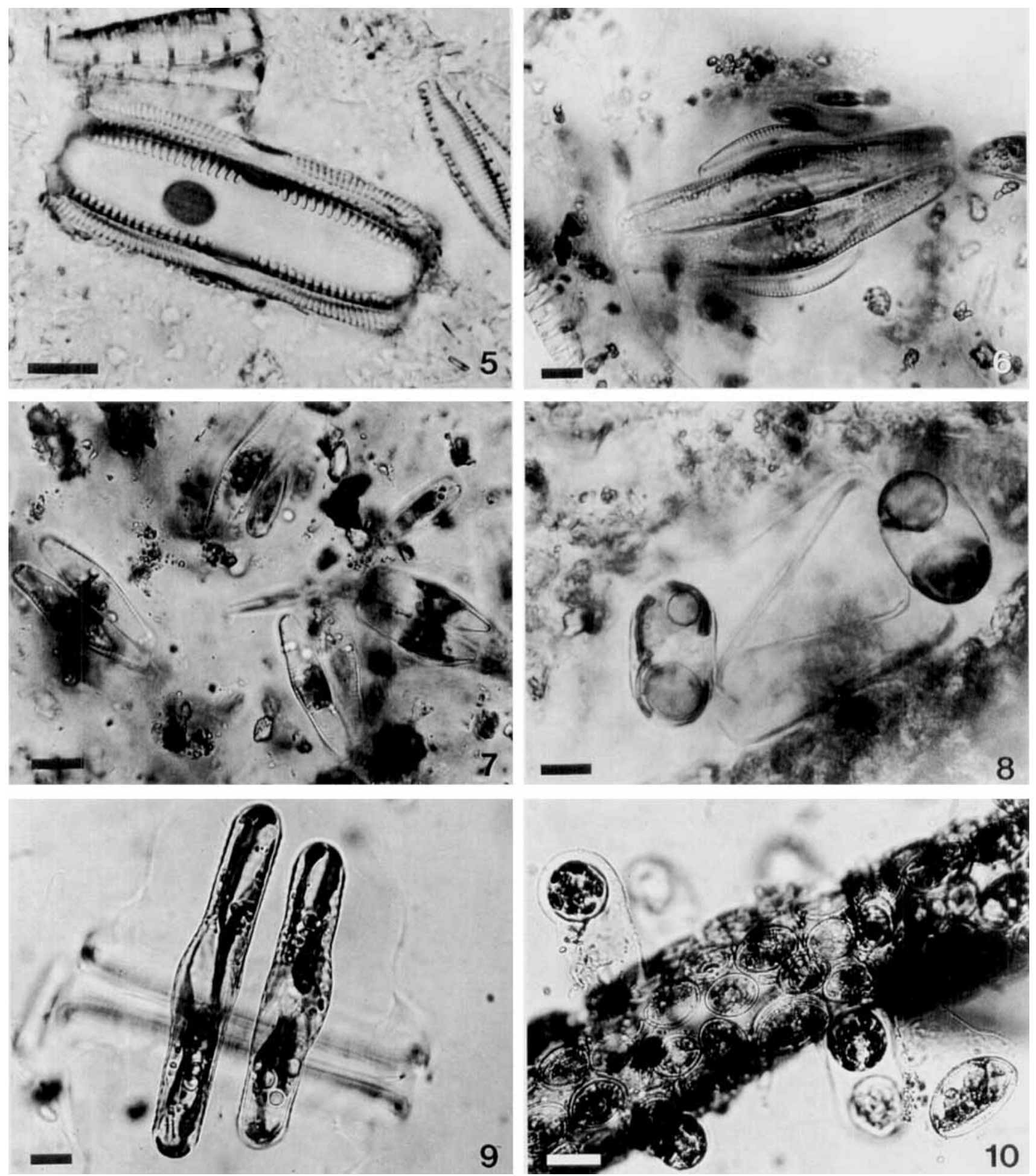

FIGS. 5-10. Life history features in pennate diatoms, Scale bars are approximately $10 \mu \mathrm{m}$. FIG. 5. An internal valve in Pinnularia sp., Cayler Prairie, Iowa, acts as a resistant stage during periods of drying. FIG. 6. Type Ia 1 physiologic anisogamy in Cymbella cistula, Hell, Michigan. Fig. 7. Synchronous sexuality by type la 1 physiologic anisogamy in Gomphonema parrulum, Huron River, Michigan. Fig. 8. Type Ic isogamy in Caloneis ventricosa (Ehrenb.) F. Meister, Tiplady Bog, Michigan. Auxospores have initial isometric enlargement and are randomly arranged in the copulation mucilage. FIG. 9. Type Ib 1 isogamy in Rhopalodia gibba (Ehrenb.) O. Müll., Silver Lake Fen, Iowa. Both progeny auxospores expand perpendicularly to the axes of the parental gametangial cells and are confined by banded perizonia. FIG. 10. Type IIa isogamy in Cocconeis pediculus Ehrenb. growing on Cladophora sp., Spirit Lake, Iowa. Single auxospores expand in a copulation sheath following the mating of single gametes produced in each of two parent cells. 


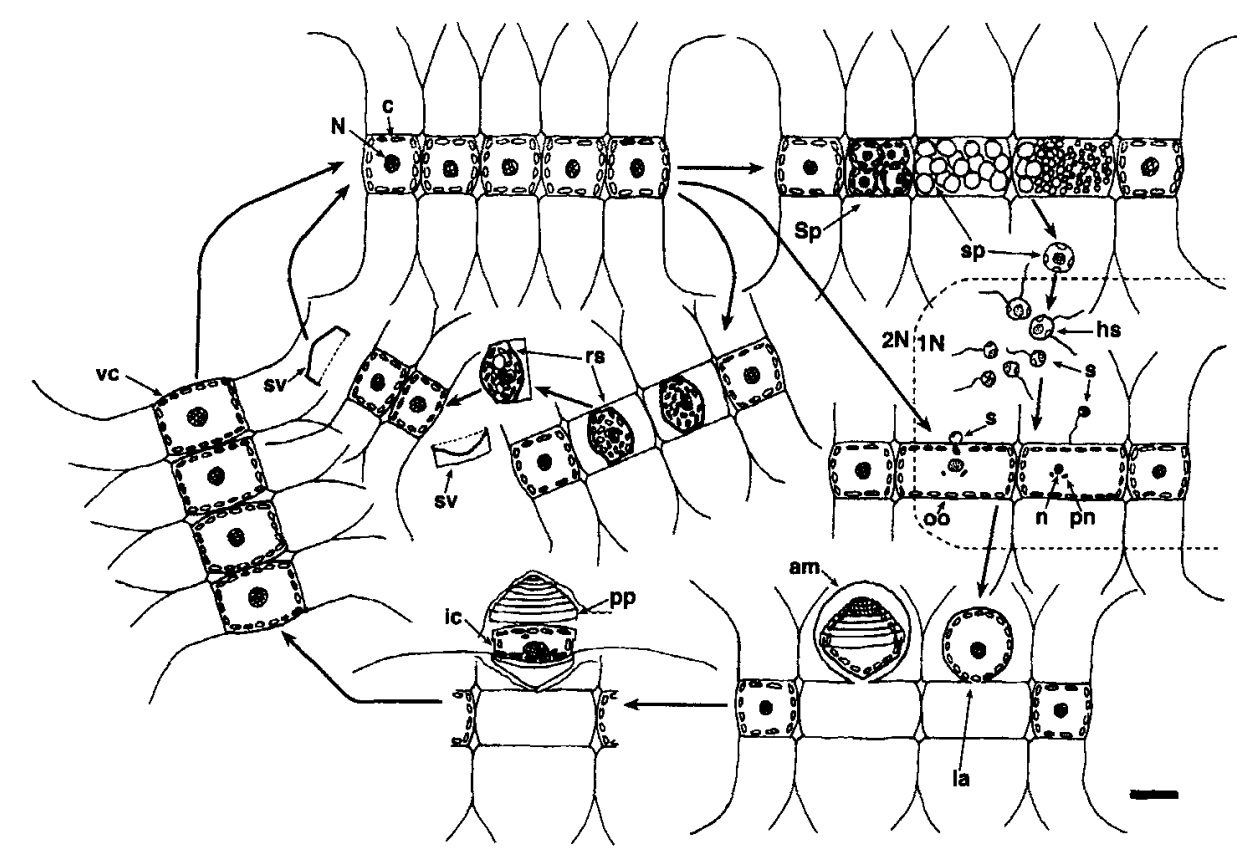

FIG. 11. Typical centric diatom life history-oogamy and resting spore formation in Bacteriastrum hyalinum. Scale bar is approximately $20 \mu \mathrm{m}$. am, auxospore membrane; $\mathrm{c}$, chloroplast; hs, hologenous sperm formation; ic, initial cell; la, lateral auxospore; N, diploid nucleus; n, haploid nucleus; oo, oogonium; pn, pycnotic nucleus; pp, properizonium; rs, endogenous resting spores; s, sperm; sp, spermatogonium; Sp, spermatogonangial filament; sv, spore valve; vc, vegetative cells; $1 \mathrm{~N}$, haploid portion of life cycle; $2 \mathrm{~N}$, diploid portion of life cycle (modified from Drebes 1972, 1974, Idei in Hori 1993).

ilar to those of centric diatoms, except that an additional pycnotic, or degenerative, nucleus results after single egg production by $R$. adriaticum Kütz. Male spermatogonia are produced by depauperizing mitoses within a filament. However, two pycnotic nuclei are produced during meiosis so that only two spermatia are formed per spermatogonium, a process more typical of pennate gamete production (Fig. 12). Contact between male and female filaments is first made before formation and release of amoeboid male gametes; fertilization is effected through an exposure in the girdle region of the oogonia (Fig. 12).

After gamete fusion and fertilization the diatom zygote or auxospore begins expansion. In centric diatoms, initial expansion is isometric (Fig. 2), but later shape modification is controlled by siliceous scales and sometimes bands or hoops in the properizonium (Fig. 11, and von Stosch 1962, 1982). Pennate auxospore expansion is also initially isometric (Fig. 8), but quickly becomes bipolar through control by the siliceous hoops, bands, and/ or plates of the perizonium (Mann 1982, 1994a), giving pennate diatoms their characteristic elongate shape (Figs. 6, 9, 13). Following expansion and growth of the auxospore, the nucleus goes through two acytokinetic mitotic divisions to create the initial cell, first depositing the epivalve, followed by the initial hypovalve (e.g. Edlund and Stoermer 1991). The initial cell of a diatom generally has the basic features of a normal vegetative cell, i.e. it is long (pennate) or round (centric). However, initial cell valves usually have modified morphology in comparison to normal vegetative valves with more rounded features, +/ - dysfunctional raphe systems, and/or irregular ultrastructure (Figs. 2-4, 6, 7, 13, Mann 1984b, Cohn et al. 1989, Edlund and Stoermer 1991, among others). Following silicification of the initial cell, two more normal cytokinetic mitoses are required to construct the first cell with normal vegetative morphology.

Variation also exists in the vegetative portion of diatom life histories. Several taxa have been shown to possess the ability to regenerate their maximum size through asexual vegetative enlargement or parthenogenesis (Geitler 1927, von Stosch 1965, Gallagher 1983, French and Hargraves 1986, Nagai et al. 1995). Other taxa, both centric and pennate, are able to prevent size diminution through modified girdle band arrangement (Geitler 1932, 1980, Reimann et al. 1966, Rao and Desikachary 1970, Round 1972, Mann 1989c). Morphologically distinct resting spores can also be present in the vegetative life history but they do not perform size restoration (Figs. 1, 11, von Stosch et al. 1973). Resting spores are especially common in neritic marine centric diatoms (Drebes 1974, Hargraves and French 1983, McQuoid and Hobson 1995, 1996) but are also produced by a few freshwater centric genera including Chaetoceros (Fig. 1), Urosolenia, Acanthoceras, and Aulacoseira (Schulz 1929, Edlund and Stoermer 1993, Edlund et al. 1996). Spore production is a mitotic process in all taxa examined to date and is associated with vegetative divisions (Ross et al. 1979) ex- 


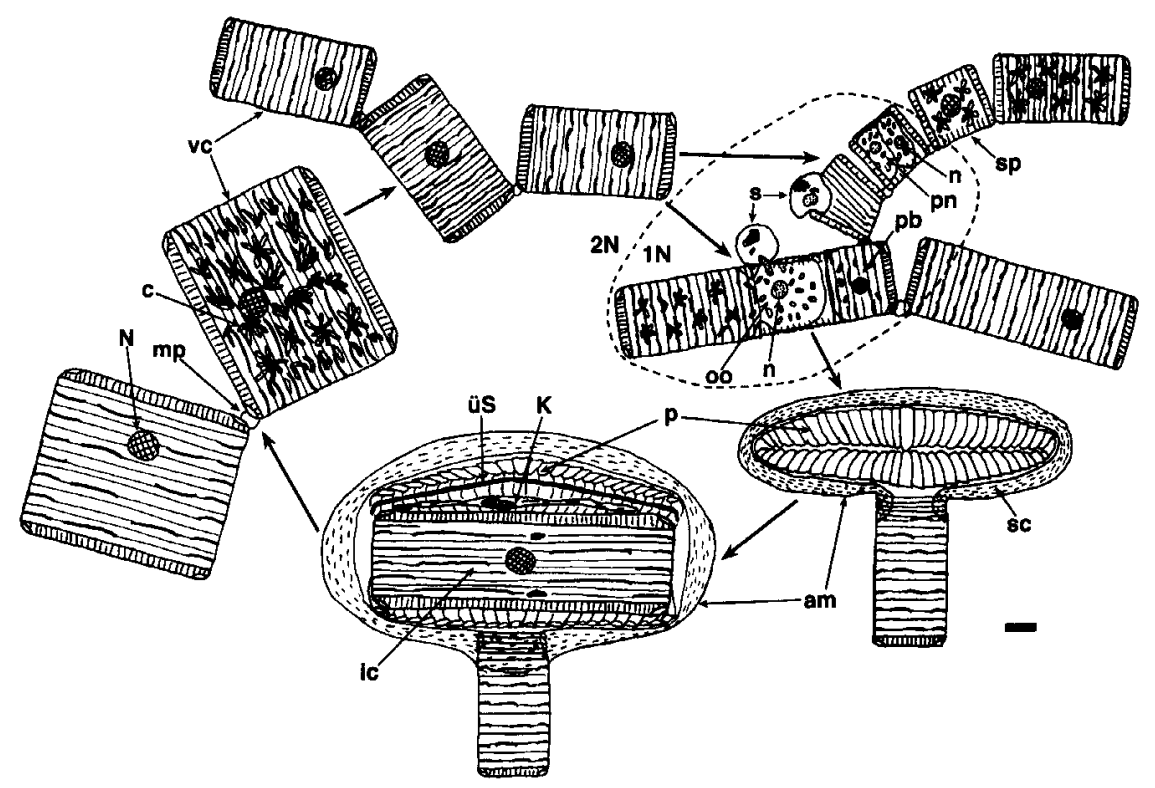

FIG. 12. Rhabdonema life history-anisogamy or "modified oogamy" in Rhabdonema adriaticum. Scale bar is approximately $20 \mu \mathrm{m}$. am, auxospore membrane; c, chloroplast; ic, initial cell; K, Kleinzelle (small degenerative cell); mp, mucilage pad; $\mathbf{N}$, diploid nucleus; $\mathrm{n}$, haploid nucleus; oo, oogonium; pn, pycnotic nucleus; $\mathrm{p}$, perizonium; pb, polar body; s, spermatia; sc, scales in auxospore wall; sp, spermatogonium; üS, überzählige Schale (surplus valve); vc, vegetative cells; $1 \mathrm{~N}$, haploid portion of life cycle 2N, diploid portion of life cycle (modified from von Stosch 1958, 1962, 1982, Mayama in Hori 1993).

cept during production of a resting spore within the auxospores of the centric diatoms Leptocylindmus danicus Cleve (French and Hargraves 1985), Cerataulina pelagica (Cleve) Hendey (Saunders 1968), Chaetoceros eibinii Grunow in Van Heurck, C. pseudocrinitum Ostenf., C. vanheurcki Gran, and Bacteriastrum hyalinum Lauder (Drebes 1977). Similarly, some pennate diatoms produce both resting spores and internal valves in response to the onset of inimical conditions (e.g. Pinnularia sp., Fig. 5). The difference between resting spores and internal valves may be more tautological than cytological. Both are produced through mitotic divisions and act as resistant stages, but pennate resting spores are defined by their requirement of a dormancy period before germination (von Stosch and Fecher 1979), differentiating

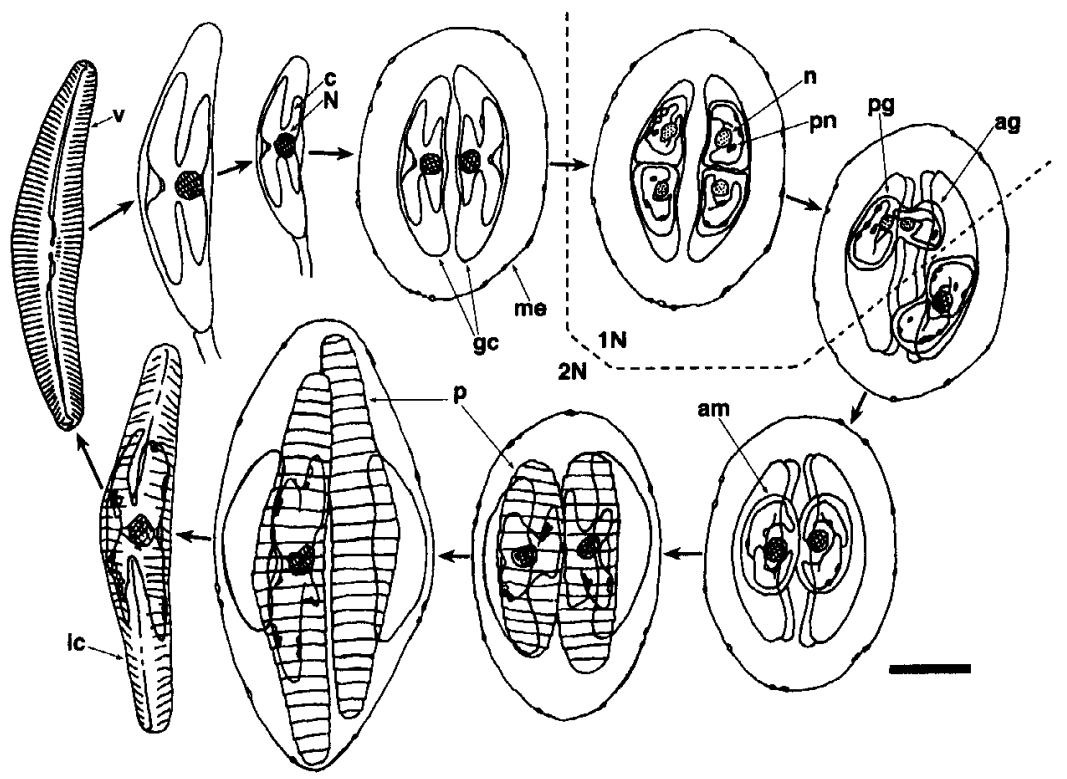

FIC. 13. Typical pennate diatom life history-isogamy or physiological anisogamy via Geitler's type Ial in Cymbella cistula. Scale bar is approximately $20 \mu \mathrm{m}$. ag, active gamete; am, auxospore membrane; c, chloroplast; gc, gametangial cells; ic, initial cell; me, mucilage envelope; N, diploid nucleus; $n$, haploid nucleus; $p$, perizonium; pg, passive gamete; pn, pycnotic nucleus; $v$, vegetative valve; $1 \mathrm{~N}$, haploid portion of life cycle; $2 \mathrm{~N}$, diploid portion of life cycle. 
them from internal valves that germinate without any dormancy requirement (Geitler 1980). The term "resting spore" is in need of clarification because most marine centric resting spores do not require dormancy for germination (McQuoid and Hobson 1996). Whether resting spores and internal valves are homologous structures (life history adaptations) within and between centric and pennate diatoms remains unresolved (von Stosch and Fecher 1979).

\section{Challenges of Studying Diatom Life Histories}

Even with over 150 years of microscopic observation, our knowledge of diatom life histories remains scant compared to other algal and higher plant groups. Recent communications among diatomists over electronic mail suggest that scientists currently recognize $\sim 20,000$ species of diatoms (although this could reach $10^{5}-10^{6}$ in the future; Mann 1994 a, Mann and Droop 1996), but only slightly more than 200 species have had significant aspects of their life history reported (Mann 1988). The paucity of reports stems from two difficulties in studying life histories. First, the incidence of diatom sexuality is, in many cases, limited to brief spates which may occur only every several years and/or may involve only a small proportion of a vegetative population (Nipkow 1928, Mann 1988, Jewson 1992a, b). Only through consistent sampling and careful microscopic examination of living or fixed material can diatomists identify the intricacies and patterns of sexuality. Second, oxidative preparatory techniques typically used for floristic, ecologic, and taxonomic studies destroy most evidence of gametangial pairing, gamete production, cytologic changes, fertilization, auxosporulation, and postsexual products. As a result of these difficulties, few scientists have taken a devoted interest in diatom life histories. A quick review of historic and current literature on diatom sexuality shows that about a dozen researchers have contributed nearly all of our knowledge on life histories.

The process of auxosporulation in centric diatoms has been known since the mid-1800s (e.g. Thwaites 1848). Several workers made significant contributions regarding the process of auxosporulation in centric diatoms, yet it was thought to be a vegetative or autogamic process (Schütt 1893, Bachmann 1904, Bergon 1907, Fritsch 1935, Persidsky 1935). Evidence of true sexual reproduction in centric diatoms remained elusive until 1950 when von Stosch conclusively documented flagellated male sperm fertilizing oogonia in Melosira varians C. Agardh. Earlier workers (Geitler 1932, Persidsky 1935) had hinted at the possibility of oogamous reproduction in centrics, and many taxa had been reported to have flagellated microspores (Schmidt 1931, Braarud 1939, Subramanyan 1946). Microspores, of course, have since been shown to be either spermatogonia or male gametes. After von Stosch's report, other workers quickly detailed oogamous sex- ual reproduction in Cyclotella (Geitler 1952) and many marine planktonic taxa including Biddulphia, Stephanopyxis, Bacteriastrum, Chaetoceros, Melosira, Skeletonema, Lithodesmium, and Coscinodiscus (Drebes 1966, 1974, Manton and von Stosch 1966, Migita 1967a, Werner 1971, von Stosch et al. 1973). Oddly enough, investigation of diatom sexuality nearly missed the transmission electron microscope (TEM) revolution from the 1950 s through the 1980 s. The studies of Manton et al. (1969a, b, 1970a, b) highlight the TEM work that has appeared on centric diatom reproduction. Few additional investigations of centric diatom sexuality have incorporated TEM (Heath and Darley 1972, Crawford 1974, Hoops and Floyd 1979). As for pennate diatoms, a few fortuitous sections of conjugating Neidium and Gomphonema represent the only transmission electron micrographs published (Drum et al. 1966).

Whereas most of these early efforts on centrics utilized cultured material to provide descriptive and cytologic observations, more recent work has begun to advance our understanding of the ecologic significance of centric life histories. Jewson (in Aulacoseira and Stephanodiscus, 1992a, b) and Waite and Harrison (in Ditylum, 1992) revealed the importance of some centric diatoms' life histories to phytoplankton dynamics in freshwater and marine environments, respectively.

Early significant advances on pennate diatom sexuality were made through the detailed microscopy of Klebahn (1896), Karsten (e.g. 1900, 1912), and Cholnoky (1927). By far the most productive worker in the field of pennate diatom sexuality was Lothar Geitler (Schmid 1991). Geitler's main interest in diatoms was sexuality and mating behavior of epiphytic pennate diatoms; this was the subject of many of his more than 100 papers on diatoms. Recent work in the laboratory of D. G. Mann (e.g. 1989c, 1993) has elucidated the life history of many epipelic pennate diatoms and shown how these observations can be used to support new ideas on diatom phylogeny, sexual compatibility, species concepts, and evolution. Additionally, initial advances in the fields of inbreeding and outbreeding in pennate diatoms have been realized in the laboratory of $A . M$. Roschin (e.g. Roschin 1990, 1994, Chepurnov and Roschin 1995), suggesting that regulatory and/or incompatibility mechanisms exist in some taxa to prevent monoecy and inbreeding.

\section{Evolution of Diatom Sexuality}

Two issues are currently debated concerning the evolution of diatom life histories. Both issues are based on the assumption or understanding that diatoms represent a monophyletic lineage (Round 1981a, b, Medlin et al. 1993). The first issue concerns the actual origin of diatoms and their diplontic life history, and the second is the evolution of isogamy (in pennate diatoms) from oogamy (in centric diatoms). 
The origin of diatoms has been pondered for many years (Korshikov 1930), but only in the last two decades has the origin of diatoms received serious consideration. Several papers by Round (1981a, b) and Round and Crawford (1981) proposed that diatoms originated before the Cretaceous from a siliceous scaled ancestor, in which two scales were modified to become valves, while the other reduced scales became girdle elements. Supportive evidence included the maintenance of scales in the postsexual auxospore diatom wall and possible homology between scales, pleural girdle elements, and "simple" radially symmetric diatom valves. Unfortunately, at that time, much work remained to be done toward inferring a phylogeny of diatoms and other closely related groups. Early hypotheses also had difficulty addressing the origin of a diplontic life history and the transition from dictyosomal scale production to silica deposition vesicles (Stoermer et al. 1965). Mann and Marchant (1989) resurrected a hypothesis that had been proposed and subsequently rejected by Round and Crawford (1981) that suggested the vegetative cell of diatoms had evolved from a scaled diploid cyst present within a haplontic life history of a scaled flagellate. The diploid cyst then developed a mitotic (rather than meiotic) germination which immediately reencysted, possibly in response to short-lived favorable growth periods. Mitotic division of the "cyst" eventually dominated the life history and was accompanied by modification of scales to create a bipolar organization with two radially symmetric valves and scale-like girdle elements.

Mann and Marchant (1989) also proposed that the gametic or haploid phase of the diatom life history evolved from a condition where biflagellate scaled isogametes dominated the life cycle. This led to a condition where periodic (or rare?) gametogenesis in the scaled diploid cyst produced naked uniflagellate male gametes capable of fertilizing oogonia protected within the siliceous wall of the mother cell. This evolutionary transformation may have been driven by marginal growth periods and fluctuating environmental conditions, which can promote the evolution and maintenance of sexuality (Crow 1992). Further ideas presented by Mann and Marchant (1989) suggest that a recently discovered group of siliceous algae, the Parmales (Booth and Marchant 1987), share morphologic and morphogenic similarity of siliceous structures with the diatoms, and may indeed share the most recent common ancestor with the diatoms.

Unfortunately, complete evidence of diatom life history evolution and the early phylogeny of diatoms and related groups is probably not preserved in the fossil record (Round and Crawford 1981, Harwood and Gersonde 1990). Recent phylogenetic (Medlin et al. 1996a, b, 1997) and fossil studies (Harwood and Nikolaev 1996) have proposed an origin of diatoms before the Lower Cretaceous, more likely dur- ing or just before the Triassic. Advances in phylogenetic systematics have also allowed molecular, morphologic, and cytologic data to be used to generate hypotheses concerning evolution and sister group relations among and between diatom groups and related heterokont organisms (Williams 1991, Bhattacharya et al. 1992, Medlin et al. 1993, Philippe et al. 1994, Sorhannus et al. 1995, Cavalier-Smith and Chao 1996, Medlin et al. 1996a, b, 1997). Although consensus has not yet been reached, an overview of current research suggests that the sister lineage of diatoms is probably composed of several chlorophyll-c-containing organisms (phaeophytes, xanthophytes, and chrysophytes) and/or the oomycetes. A most recent common ancestry between the diatoms and their sister lineage is supported, in part, by shared diplontic life histories in most Heterokonta (some phaeophytes, oomycetes, xanthophytes). Medlin et al. (1997) have suggested that the "most parsimonious explanation" of diplontic life history evolution in diatoms is contrary to the proposal of Mann and Marchant (1989). Medlin et al. (1997) suggest instead that the most recent common ancestor of diatoms and its sister lineage already had a diplontic life history; however, additional evidence supporting these sister group life history relations is needed. In particular, knowledge of life history types in some of the heterokont algae, details on the arrangement and/or reduction of the flagellar apparatus as a single pleuronematic flagellum (diatoms vs. Chromulina, Dictyota), and an understanding of physiologies that include production of siliceous structures in some of these groups would be welcome (Pascher 1921, Al-Kubaisy et al. 1981, Williams 1991, van den Hoek et al. 1995).

The second puzzling issue is the evolution of diplontic life history variability within the diatom groups. Rather than the more traditional evolutionary transformation series of isogamy to anisogamy to oogamy found in some other algal groups (Parker 1971), diatoms appear to have progressed through this evolutionary pathway in reverse. The first diatoms, or at least the oldest known in the fossil record, were centric and assumed to be oogamous (Harwood and Gersonde 1990). The fossil record further suggests that araphid diatoms were the next major group to arise, finally followed by the appearance of the raphid diatoms (Small 1945, Simonsen 1979, Tappan 1980). Araphid and raphid diatoms are functionally isogamous, except for the araphid Rhabdonema, which utilizes anisogamous or "modified oogamous" sexuality (Fig. 12). The evolutionary sequence of oogamy to isogamy can be further investigated using results of recent molecular phylogenies.

Medlin et al. (1993, 1996a, b, 1997) have developed phylogenetic proposals using molecular data that suggest both centric and araphid groups represent paraphyletic lineages. Their hypotheses (Medlin et al. 1993, 1996a, b, 1997) corroborate the 


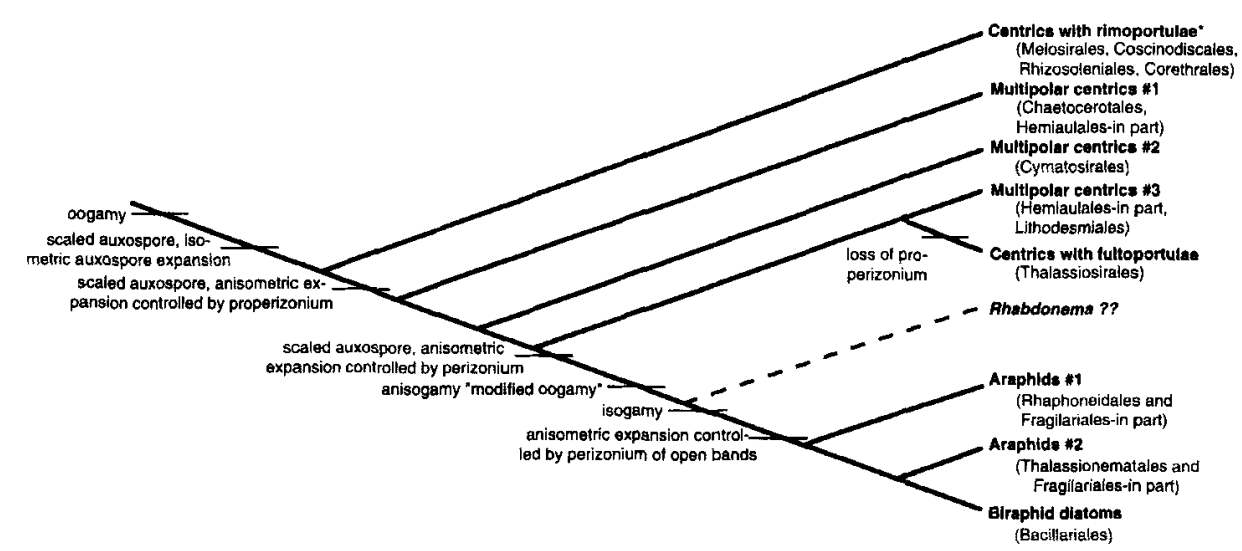

FIc. 14. A current hypothesized phylogeny of diatoms based strongly on the molecular analyses of Medlin et al. (1993, 1996a, b, 1997), Bhattacharya et al. (1992), Phillipe et al. (1994), Sorhannus et al. (1995), and Cavalier-Smith and Chao (1996). Presently the centric and araphid diatoms represent paraphyletic lineages as supported by molecular phylogenetic analyses. We hypothesize the location of Rhabdonema on this tree to represent a transitional lineage between the centric and pennate (araphid and raphid) diatoms. Some life history character state changes that support this topology have been mapped onto the tree. Ordinal classifications follow Round et al. (1990).

* Several taxa included in this clade (e.g. Corethron) do not possess rimoportulae due to an apparent evolutionary character loss.

time of appearance of major groups in the fossil record fairly well (Simonsen 1979). We have reconstructed one current phylogenetic hypothesis (Fig. 14) based strongly on not only the molecular analyses of Medlin et al. (1993, 1996a, b, 1997), but also on Bhattacharya et al. (1992), Phillipe et al. (1994), Sorhannus et al. (1995), and Cavalier-Smith and Chao (1996). Although these studies are not in complete agreement on terminal branch topology, they support a monophyletic origin of diatoms. Within the diatom lineage, the centric diatoms are a paraphyletic group with separate clades supported by molecular data leading to radially symmetric taxa with only rimoportulae, three lines of multipolar centrics, and a clade containing the centrics with strutted processes sharing a most recent common ancestor with the Hemiaulales and Lithodesmiales. The araphid diatoms form two paraphyletic lineages, whereas the biraphid diatoms terminate the tree as a monophyletic group. We have hypothesized that Rhabdonema represents a separate lineage originating before other araphids (Fig. 14), although it has not been used in molecular phylogenies to date. Using this phylogenetic hypothesis, it is possible to map the major character changes in sexuality among the diatom groups (Fig. 14). The centric diatoms are a paraphyletic group, and except for some examples of automixis and parthenogenesis, all extant taxa investigated reproduce sexually via oogamy, the proposed ancestral state. With the exception of Rhabdonema and Grammatophora (von Stosch 1958, Magne-Simon 1962), which have been implicated as representing a transitional state in this evolutionary sequence, the more recently evolved araphid and raphid lineages undergo isogamy or physiologic anisogamy. Several features of Rhabdonema sexuality support a hypothesis that this life cycle may represent a transitional state (von Stosch 1958, 1962) be- tween oogamy and isogamy (Fig. 14). Rhabdonema reproduces anisogamously (Fig. 12). Smaller maledetermined filaments attach to female filaments, undergo meiosis and produce only two amoeboid spermatia per male gametangial cell. Two pycnotic nuclei are also produced during male Rhabdonema gametogenesis, whereas all meiotic nuclei survive in centric male gametogenesis. Both the pairing that is effected by male filaments and the reduction to two amoeboid gametes per male cell are more characteristic of pennate pairing and gametogenesis. The cytology of egg production in Rhabdonema is more similar to centric oogenesis. One or two gametes are produced per female cell depending on Rhabdonema species. In $R$. arcuatum (C. Agardh) Kütz., two eggs, each with a pycnotic nucleus are produced. In $R$. adriaticum a single egg is produced along with a secondary polar body containing two pycnotic nuclei, a scenario dissimilar to centric egg production, but identical to gamete production in Grammatophora. Other shared features between centric oogamy and Rhabdonema are found in the postsexual products. Rhabdonema represents the only pennate diatom with a scale-invested auxospore wall like nearly all centric taxa (von Stosch 1982, but see Mann 1984a). However, in addition to scales, Rhabdonema also has a siliceous perizonium made of open hoops (Fig. 12) and sometimes longitudinal bands similar to the perizonia found in isogamous pennate taxa (von Stosch 1962, 1982). It will be interesting to see if Rhabdonema occupies a transitional lineage between the centric lineages and the araphid lineages, as we have hypothesized (Fig. 14), when its molecular and morphologic evolutionary characters are analyzed.

The evolutionary transformation series of isogamy-anisogamy-oogamy seen in many other algal groups (Parker 1971) has not occurred in diatoms. In moving from isogamy to oogamy, increased stor- 
age capacity of oogonia and more efficient fertilization energetics have been suggested as evolutionary triggers. However, in diatoms the selective pressure appears instead to have been an evolutionary progression toward effecting successful pairing of gametes. In the centric diatoms, sperm are released into the aquatic environment, presumably to find and fertilize the oogonia by the combination of chance and chemotactic attractants (Idei and Chihara 1992). Rhabdonema, in contrast, initiates pairing between male and female filaments before gamete release, effectively increasing the chances of successful fertilization. Other pennate diatoms, both araphid and raphid, effect pairing via mucilage envelopes (Figs. 6-10), pads or copulation tubes, or simply close physical arrangement (e.g. Diatoma, Tschermak-Woess 1973). Even araphid taxa, normally incapable of movement (however, see Pickett-Heaps et al. 1991), hold paired sexual partners together with mucilage pads (e.g. Synedra, Geitler 1939). This evolutionary trajectory appears to be a transfer of function (Mann 1993) from the gametes pairing, to the gametangial cells actually initiating pairing. This latter state is known as gametangiogamy and is evident in other algal groups with haploid life histories, notably the Zygnematales. This apparent example of convergent evolution toward gametangiogamy has not escaped previous workers (Wiese 1968, Nakahara and Ichimura 1992).

\section{Sexuality and Phylogenetic Systematics}

Beyond a general support of diatom phylogeny, the transition from oogamy to anisogamy to isogamy as outlined above contains many detailed stages that may provide additional characters to foster phylogenetic investigations of diatoms. The increased interest in phylogenetic systematics (Kociolek et al. 1989, Theriot 1989) has prompted some use and evaluation of sexual characters as evidence of phylogenetic relationships. Mann (e.g., 1993, 1996) has continued to describe properties of sexuality in pennate diatoms that might support relatedness among organisms, although these homologies remain to be tested formally. Kociolek and Stoermer (1989) used initial valve size as a multistate character in an analysis of Gomphoneis. Theriot (1992) also used auxospore size as a character in a phylogenetic analysis of the Stephanodiscus niagarae Ehrenb. complex. Both of these studies suggested that postsexual maximum size of a taxon can lend additional support to morphologic characters in phylogenetic analyses. Caution must be exercised when interpreting characters of sexuality in an evolutionary context. PassyTolar and Lowe (1995) incorrectly adhered to Haeckel's law ("ontogeny recapitulates phylogeny") by suggesting that characters present in the initial valve of Gomphoneis represent an ancestral condition when compared to characters in the vegetative valve. This approach may seem attractive for interpreting ontogenetic changes within a species; however, it has been strongly criticized (Gould 1977, Alberch et al. 1979, Williams 1994). A more appropriate method is to compare character states or ontogenies among and between taxa, rather than comparing ontogenetic character states within a taxon, first insuring that characters pass the criteria of similarity and independence (Theriot and Serieyssol 1994). Williams $(1994,1996)$ applied this approach to compare valve shape among Tetracyclus by using pre- and postauxospore shape to properly code ontogenetic shape changes.

Other aspects of the diatom life history also hold promise for their systematic value. The siliceous components (scales, properizonium, epizonium, perizonium) that control development of the auxospore into the initial cell have been suggested to be a source of putative homologies to test relationships within the diatom lineages (Fig. 14). Von Stosch (1982) proposed an evolutionary transition series from a scaled auxospore wall with isometric growth, to anisometric auxospore growth controlled by properizonial closed hoops, to anisometric growth controlled by closed hoops and open bands, and finally to anisometric auxospore growth controlled by open bands. This ordered series is well supported in current phylogenies (Fig. 14) if properizonial elements are considered lost in the Thalassiosirales.

Whereas it might seem that more reproductive characters would be excellent for phylogenetic analyses, many are problematic. The loss of silica scales from the auxospore wall is an apparent homoplasy among distantly related taxa including Stephanodiscus (Round 1982, Edlund and Stoermer 1991, Jewson 1992a), Aulacoseira (Crawford 1975, Jewson 1992b), and all pennate taxa except Rhabdonema (von Stosch 1982). Within the centric diatom lineages, the number of oogonia was proposed by Drebes (1977) to represent a potential transformation series from ancestral production of two oogonia to a single oogonium plus a polar body to the more derived single egg. Unfortunately, even within individual genera (e.g. Biddulphia) different species utilize different oogenic mechanisms, making comparisons difficult. Additionally, lineages with more derived morphologic features, that is the multipolar centrics, commonly produce two oogonia. The two types of spermatogenesis, merogenous and hologenous (Drebes 1977), present a similar confusing evolutionary scenario. Merogenous spermatogenesis results in the production of four sperm and a residual body containing cytoplasm and chloroplasts from the spermatogonium because cytokinesis occurs only after both meiotic divisions are complete. Hologenous sperm are produced following two equal cytokineses following each meiotic division; all four sperm thus contain an equal proportion of nuclear and cytoplasmic material from the spermatogonium. In general, the radially symmetric centric dia- 
toms undergo merogenous spermatogenesis, whereas the multipolar centric lineages have hologenous spermatogenesis (e.g. Bacteriastrum hyalinum, Fig. 11). But taxa that are apparently closely related (e.g. Skeletonema and Thalassiosira) use hologenous and merogenous spermatogenesis, respectively (Migita 1967b, Idei in Hori 1993). As additional evidence, Jewson (1992a) and Schmid (1995) recently illustrated unique forms of spermatogenesis in Stephan odiscus cf. neoastraea Håk. and B. Hickel and Coscinodiscus granii Gough. This exemplifies the main problem associated with our current understanding of life histories. Evidently many character states are in need of extensive analysis, but because so few taxa have been investigated, a complete comprehension of the intricacies of life histories is lacking.

Other life history areas that could provide valuable characters for future systematic efforts include variations in the pennate forms of sexuality. Mann (1993) criticized the current pennate sexuality classification scheme (Geitler 1932, 1973, 1984) by suggesting that gamete and auxospore number were less important in the evolutionary development of sexuality than pennate gamete behavior. Mann (1993) proposed that type IA2 sexuality (physiological anisogamy, both active gametes in the same gametangium) was ancestral among the allogamous forms of pennate sexuality. The argument seems meritorious from a phylogenetic viewpoint, since many araphid taxa (e.g. Licmophora, Diatoma, Striatella, Synedra) use this type of sexuality. From type IA2, Mann (1993) suggested that the other forms of sexuality could have evolved through reduction and/ or breakdown of incompatibility mechanisms. Recent work by Roschin (1994) has provided supplemental support of Mann's ideas. Of the type IA2 araphid taxa that have had mating types investigated, most are dioecious, a condition that Roschin (1994) and Roschin and Chepurnov (1996) proposed to be ancestral to the more commonly reported monoecy.

\section{Costs and Benefits of Sexuality}

The widespread occurrence of sexuality in higher organisms has traditionally been analyzed using a cost : benefit analysis (Fisher 1930, Maynard Smith 1978). Simply put, maintenance of sexuality within the life history of an organism should be justified by benefits greater than costs (Lewis 1987). In higher organisms, costs are often negligible due to nonlethal and multiple sexual episodes; however, singlecelled eukaryotes present different types of sexual costs and benefits than higher organisms.

Some benefits of sexuality in diatoms are common among all sexual organisms (Richardson 1995). First, maintenance of sexuality allows genetic recombination to occur. As a result, adaptive radiation, natural selection, and outbreeding (Roschin 1990) are possible in sexual organisms, allowing genotypic diversity and heterozygosity to increase
(Lewis 1987, Crow 1992), a realized benefit to organisms living in patchy environments (Waite and Harrison 1992). In addition, cellular functions associated with sexuality are maintained, such as DNA repair and purging of deleterious alleles. Richardson (1995) also suggested that sexuality within clonal diploid organisms (many diatoms are monoecious) can result in expression of homozygous recessive alleles, a trait that may well prove advantageous to an isolated population. A very important benefit that is realized specifically by diatoms undergoing sexuality is size restoration (Figs. 2-4, 6). Because of constraints imposed by the cell wall and division mechanism in diatoms, sexuality remains the sole mechanism for restoring most cell lines to their maximum size. It is also a well-known fact that diatoms that slip below the size of sexual induction die or are quickly purged in natural environments (Mizuno and Okuda 1985); but, in the absence of competition and predation, they may stay alive in culture for years (Round 1993). An unfortunate result of this is that many ecologic and physiologic experiments are performed on diatoms in a highly atypical state. An additional benefit of sexuality, thus far specific to diatoms, is the recovery of form. In some genera (e.g. Cocconeis, Surirella), it is common for aberrant forms with misshapen valves to occur, usually as the result of mechanical damage, and be perpetuated through mitosis. Sexuality permits these cell lines to recover normal morphology during auxosporulation (Drum 1964, Mann 1994a).

The costs of sexuality for single-celled organisms can run very high. As with all sexual organisms, there is a potential for reduced fitness in offspring following recombination, as novel genomes are expressed. Sexual parents are also considered to have reduced fitness compared to asexual parents as measured by their genomic contribution to potential offspring (Richardson 1995) and the potential loss of successful parental genotypes (Murphy 1978, Waite and Harrison 1992). The production of males (sperm) and the accompanying loss of male chloroplast material is also a significant cost factor to centric diatoms and Rhabdonema. There are especially high costs for diatoms associated with failure-tomate; this leads to lack of size restoration and potential death. Pennate diatoms may have evolved mechanisms to reduce failure-to-mate costs through an ability to halt or revert the induction and pairing process preceding gametogenesis. Unlike centric diatoms, which are fully committed to gametogenesis after induction (Drebes 1977), pennate diatoms may be able to abort gamete formation even after pairing (Mann 1993). A second mechanism for minimizing failure-to-mate costs has been termed the "diatom sex clock" (Lewis 1984). The size diminution process in diatoms allows for the possibility of multiple attempts at sexual reproduction. If a situation arises when the sexual induction factors (cell size and environmental conditions) are not coinci- 
dental, a diatom can continue to divide and potentially stay within the sexually inducible size range until such time when the correct environmental conditions occur for induction (Lewis 1984). Schmid (1995), in an elegant study on the centric Coscinodiscus granii, reported a novel mechanism for "beating the clock." Male-determined cells formed spermatogonangial tetrads, but in some cases, one or more spermatogonangial cells within the tetrad were able to revert to vegetative growth. Schmid (1995) suggested that the failure-to-mate costs in centrics were further minimized by fewer cells participating in oogonial formation (one oogonium for every 24 spermatangia) and more effort toward male gamete production to maximize success of fertilization. Crawford's (1995) observations on Corethron criophilum Castrac, and Waite and Harrison's (1992) study of Ditylum support this high male : female ratio strategy in centric diatoms.

A poorly studied cost of sexuality in diatoms is the ecological cost (Reznick 1992), that is costs associated with increased risk from disease, injury, or predation during reproduction. These costs may be a significant factor, especially for centric diatoms. Jewson (1992a) reported that both spermatangia and sperm of Stephanodiscus were favored prey items of rotifers and dinoflagellates, respectively. Pennate diatoms probably have minimal ecologic costs as most are enclosed within a mucilaginous matrix during pairing and copulation. Last, physiologic (Reznick 1992) or cellular-mechanical (Lewis 1983, Waite and Harrison 1992, Richardson 1995) losses also present high sexuality costs for diatoms. The time required for sexuality is much longer than that required for vegetative mitosis (Lewis 1983). Loss of potential asexually produced offspring and the associated loss of cellular production during the time of sexuality is significant. There are also appreciable losses of cellular material during sexuality. To truly appreciate this cost, one may consider only the loss of siliceous components during sexuality. A complete frustule is lost from each parent cell, siliceous components associated with the auxospore wall (scales, properizonium, epizonium, and perizonial elements) are lost in one or two daughter cells, and a complete frustule (comprised of the initial valves) is lost from each daughter product (Edlund and Stoermer 1991).

Although it is not difficult to list the costs and benefits of maintaining sexuality within a life history, actual quantification and scaling of these factors is very difficult and controversial (Stearns 1989). We are aware of no published studies on diatoms that have specifically addressed this issue using life history manipulations, phenotype or genetic correlation, or forced selection (Reznick 1992). Although the costs of sex may seem insurmountable, the major benefit of sexuality for most diatoms is that it remains the sole mechanism of size restoration. Without episodic sexuality, a diatom population will continue to divide below the sexually inducible size range, until cells are so small that they exhibit abnormal morphology ("Kummerformen"), are unable to synthesize enough reserves for mitosis, and eventually die. Richardson (1995) suggested that the dominance of asexuality in the diatom life history probably provides sufficient rates of mutation to drive evolutionary changes within this group beyond that gained through sexuality. However, Richardson (1995:135) further contends that the maintenance of sexuality with a predominant asexual period "seems to be a very successful life history strategy that preserves successful forms in clonal purity while also providing oppportunities (sic) for evolutionary innovation.",

Although little work has directly addressed the importance of diatom sexuality, one intriguing study showed a taxon was locally extirpated when conditions changed sufficiently to prevent sexuality. Stoermer et al. (1989) analyzed the subfossil sediment record in Lake Ontario and inferred that conditions had deteriorated from anthropogenic modification to such an extent that Stephanodiscus niagarae was unable to undergo sexual reproduction. Paleolimnologic data suggested that historical sexual periodicity of $S$. niagarae in Lake Ontario had been approximately decadal, but after 1947, largecelled specimens could not be found. It was suggested that depletion of the seasonal supply of silica in offshore waters prevented sexuality and size regeneration. Modern collections from Lake Ontario still contain a few cells of $S$. niagarae because of a continuing supply of cells from upstream Lake Erie; however, the Lake Ontario cells are a small-diameter population, presumably below the sexually inducible size range.

\section{Recent Ideas on Size Diminution}

MacDonald (1869) and Pfitzer (1869) simultaneously proposed a hypothesis to explain size diminution in vegetatively growing diatoms. Namely, the resultant population size distribution from a single mitotically dividing cell could be explained by the binomial expansion because a single diatom divides to form two cells, one identical to the parent and the second smaller by a factor equal to twice the thickness of the cingulum (girdle bands). These generalizations are rarely borne out precisely because of cellular-mechanical differences in cingulum structure among taxa and cingulum changes associated with cell size within species (Crawford 1981, Medlin and Fryxell 1984, Jewson 1992a). The situation is further compounded by different growth rates between mitotic parents and progeny cells (Rao and Desikachary 1970, Round 1972). Regardless, there remains the necessity of size diminution as a precursor to sexuality in most diatom taxa. Geitler (1932) proposed that each taxon's life history contains two critical cell sizes, which he termed cardinal points ("Kardinalpunkte"). The first cardinal 
point describes the size that cells must reach before they can undergo sexual induction to become gametangia. The second cardinal point describes postsexual reproductive cell size, or the largest size that a taxon can attain following auxospore expansion. Because of the cellular-mechanical constraints of frustule construction, the division rate and/or number of divisions necessary for a taxon to move between its two cardinal points before engaging in sex should be very predictable (Hostetter and Hoshaw 1972, Mizuno 1991). Recent advances in our understanding of size diminution have, however, revealed how difficult this phenomenon is to predict because of environmental and genetic size selectivity, limited lifespans of diatom valves, and variation in cardinal point characteristics among and within species.

Environmental and biologic factors may select for or against certain size classes within a diatom species. For instance, selection for smaller cells will more quickly bring a population to a sexually inducible size range. Mann (1988) identified that larger cells of Nitzschia sigmoidea (Ehrenb.) W. Sm. were more likely to be parasitized by an oomycete, which inevitably led to a selection for a smaller celled population, and Francis and Edlund (1994) reported that larger epipelic diatoms were selectively grazed by chironomid larvae. The selection process can also work in reverse, selecting for survival of larger cells. Jewson (1992a) showed that smaller cells of Aulacoseira subarctica (O. Müll.) E. Y. Haw. were selectively infected by the chytrid Zygorhizidium melosirae and more heavily grazed by benthic chironomids and oligochaetes. Additional control of cell size by environmental factors is reflected in changes in growth rates due to nutrient, light, and trace elements (Paasche 1973, Fisher et al. 1981, Taylor 1985). Faster growth rates will more quickly effect the transition of a population to its inducible size range. In addition to growth rates speeding this transition, poor environmental conditions and slow growth periods have also been reported to be the time of largest size decrease per mitotic division in populations of Aulacoseira, Stephanodiscus, and many marine and estuarine species (Jewson 1992a, b, Mizuno 1991). For instance, in Stephanodiscus cf. neoastrea, large-diameter cells produced "smaller-than-expected" hypovalves during periods of slow growth (Jewson 1992b).

In addition to environmental factors affecting size diminution rates, there is also evidence that genetic differences exist within a species that are reflected in variable size diminution rates among clones. Wiedling (1948) and Armbrust and Chisholm (1992) showed variable size diminution rates among different clones of the same taxon under similar growth conditions. Grover (1989) suggested that control of size diminution may have competitive value, especially for centric diatoms, which are more competitive for phosphorous at smaller sizes.

Cellular-mechanical constraints of frustule con- struction that may control size diminution rates have also been reported. In both Cocconeis and Aulacosei$r a$, diameter decrease per division was greatest in larger cells (Mizuno 1991, Jewson 1992a). Jewson (1992a) suggested that this phenomenon occurred in Aulacoseira due to thicker cingulum bands in larger cells, which implies that cells that reach a sexually inducible size range are maintained in that size range longer. Hostetter and Hoshaw (1972) also identified variable size decrease in cultures of Stauroneis anceps Ehrenb.; the largest size decrease per generation was found in the middle size range of cells. A physiologic characteristic, higher growth rates in smaller cells of some species, also enhances size reduction rate (Williams 1964, Banse 1976, Mizuno 1991). A third recent observation on cellular control of size diminution is perhaps the most intriguing development toward understanding this process. Mann (1988) and Jewson (1992a, b) have reported that diatom cell size classes, hence valves, have determinate life spans. For Stephanodiscus cf. neoastrea, Jewson (1992b) calculated that each valve and its cingulum lasted only through six to eight vegetative divisions. Jewson further suggested that this enhanced the rate of size reduction by removing larger cells from the population so that they would not compete for resources with smaller cells dividing to reach the sexually inducible size range. Good evidence for this principle comes from observations on the determinate number of divisions in initial cells. Edlund and Stoermer (1991) and Jewson (1992a, b) noted that after just a few divisions, cells that contained the original valves from the initial cell ceased division and were lost from the population.

A few taxa have been reported to also have the ability to undergo "rapid size reduction" (Kling 1993), probably in response to limiting nutrients. This characteristic seems to be most commonly reported in freshwater àraphid genera, e.g. Asterionella, Tabellaria, Synedra, and Fragilaria (Nipkow 1928, Locker 1950, Roessler 1988, Kling 1993) and may enable a cell line facing limiting conditions to more quickly reach the sexually inducible size range.

As previously noted, the inducible size range for gametogenesis is one of the cardinal points proposed by Geitler (1932); the size of the initial cells is the other cardinal point. These points have classically been considered to be species specific, reflecting the full range of sizes that a taxon can achieve during size reduction. While Geitler (1932) suggested that cardinal points represent discrete and narrow size intervals, more recent work and some resurrected older literature show that postsexual cells often have a wide size range both within and between species populations (Bethge 1925, Nipkow 1928, Skabitschewsky 1929, Drebes 1974, Mann 1984b, 1988, Kociolek and Stoermer 1989, Edlund and Stoermer 1991, 1996, Jewson 1992a, b, Davidovich 1994, Schmid 1995). For example, Edlund and 
Stoermer (1991) investigated a monoecious culture of Stephanodiscus niagarae undergoing sexuality (Fig. 2) and compared it to a collection of postsexual cells of $S$. niagarae collected in 1878 from the same watershed. They found, in addition to a large size range of initial cells being formed in each collection, that there was a significant difference between the mean size of the two postsexual populations. Data of Stoermer and Ladewski (1982) for the type population of Gomphoneis herculeana (Ehrenb.) Cleve suggest the same phenomenon. Both of these historically differentiated populations came from the Laurentian Great Lakes, an area of gross ecological disturbance, and may indicate a type of morphologic diminution caused by ecologic change. Although we are not aware of any formal studies, casual observation suggests that between nominally conspecific populations, the mean and maximum size are larger for those collected before human landscape disturbance than in their modern descendants. Mann (1984b) noted a similar problem in several populations of Rhoicosphenia curvata (Kütz.) Grunow ex Rabenh. and suggested that different size initial cells may provide evidence of infraspecific races. Armbrust and Chisholm (1992) showed that, among many isolates of Thalassiosira weissflogii Grunow, the mean maximum cell size following sex varied significantly. In addition, within a single clone, the maximum cell size also varied as a clone went through several sexual events.

The smaller cardinal point has also been shown to vary across a wide range of cell sizes within a taxon (von Stosch 1967, Drebes 1974, Hargraves and French 1983, Mann 1988, Armbrust et al. 1990, Waite and Harrison 1992). Schmid (1995) provided the most dramatic evidence of this in Coscinodiscus granii, showing that the sexually inducible size range for gametangial cells overlapped the size of initial cells. Waite and Harrison (1992) were even able to induce gametogenesis in postauxospore cell lines of Ditylum brightwellii (T. West) Grunov in Van Heurck.

This evidence of variation in gametangial and initial cell size does not conform with our traditional view, the cardinal point hypothesis, and only highlights the need to seek greater understanding of factors controlling auxospore expansion, factors initiating sexuality, and the degree to which these differences may reflect genetic change or provide characters for species identification. At the cytologic level, the period of auxospore expansion appears to be accompanied by a breakdown of the cytoskeleton, which later reorganizes after expansion is complete (Schmid 1984). Additionally, the importance of size in these cardinal point cells is probably critical to a taxon's autecology and needs further testing. Mann (1993:16) suggested that ". . . zygote size is likely to be highly correlated with the fitness of the offspring," and Davey (in Aulacoseira, 1986) noted auxospore size was critical to a population balancing the costs of increased sinking rate from larg- er cells with the high cost of repeating sexuality too frequently. Round's (1982) observations seem to bear this out; he noted a quick loss of initial valves in nature following sexuality in Stephanodiscus, purportedly from the initial cell's greater volume and weight, rapid sinking, and possibly greater susceptibility to grazing.

Finally, these new ideas on size diminution and contradictory evidence on cardinal points affect Lewis' (1984) "diatom sex clock." Recall that Lewis' "clock" allowed for supraannual sexuality in diatoms because, if sexuality did not occur in one year, the size diminution process would likely allow another group of cells to be in the inducible size range when environmental conditions became favorable in following years. Furthermore, during a sexual event, a taxon would not have to commit its entire population to sexuality as a portion is likely to be outside the inducible range. Loss of the traditional predictability in the diatom life cycle, that is size diminution between discrete cardinal points, may interrupt Lewis' clocking mechanism. For instance, starting with a wide range of initial cell sizes would more quickly create a population with greater size variance (and may be an avoidance mechanism for size-selective herbivory) and more quickly bring a portion of the population within a sexually inducible size, perhaps even annually (Round 1982). However, to counter this argument, it is just as easy to suggest that environmental and cellular-mechanical means of controlling size diminution rates, limited valve lifespan, and the cardinal point breakdown are only evidence of past selective pressures that fine tune the sex clock.

\section{Ecology of Life History Strategies}

As our understanding of diatom life histories has emerged from its infancy, much current work remains descriptive. New types of pennate sexuality have recently been discovered (Stickle 1986, Lee and Xenophontes 1989, Jewson and Lowry 1993, Mizuno 1994, Main 1995), and greater detail on the processes of sexual determination, induction, and gametogenesis in centric diatoms has been reported (Roschin 1994, Schmid 1995). However, we are also beginning to appreciate the autecologic and synecologic impacts of diatom life history strategies and how they relate to physical, chemical, and biologic facets of aquatic ecology. Efforts are being directed at not only studying sexuality in cultured taxa but applying laboratory results to the role of sexuality in natural populations.

The frequency of sexuality in natural populations has been studied in both marine and freshwater settings. The timing of sexuality is, of course, related to size diminution and cytologic and environmental induction factors. Life cycles in natural populations have been shown to range from 2 years up to possibly 40 years (Nipkow 1928, Skabitschewsky 1929, Round 1982, Mann 1988, Stoermer et al. 1989, Jew- 
son 1992a, b). However, in some systems, annual incidence of sexuality has been suggested, where cohorts are produced annually and then cycle through several years of size diminution until eventual sexual induction (Mizuno and Okuda 1985, Jewson 1992a, b). Probably the most surprising aspect of current work is that through careful observation, sexuality has been found to occur much more regularly in nature than might have been expected, given the paucity of literature reports. The lack of reports may, and probably does, reflect the often small proportion of a population that goes through sexuality, the limited duration of sexuality, or the loss of sexual products such as initial valves (Round 1982, Edlund and Stoermer 1991, Jewson 1992b, Schmid 1995). In several cases, rather than identifying sexual stages, restoration of size has provided the sole evidence of "sexuality" in epipelic, epiphytic, and planktonic communities (Bellinger 1977, Mizuno and Okuda 1985, Mann 1988). Periphytic diatom communities are more commonly reported to show annual sexuality, usually because of the large number of cells engaged in sexual reproduction. Geitler's monumental efforts were often based on natural collections, and it is common to find mass sexuality in springtime collections, for example, Didymosphenia geminata (Lyngb.) M. Schmidt (Meyer 1929), Gomphonema parvulum Kütz., and Cymbella cistula (Ehrenb.) O. Kirchn. (Figs. 6, 7).

Over the last 15 years, a broader view of the ecology of sexuality has been realized. Based on a literature survey of periphytic and planktonic taxa, Drebes (1977:274) wrote, "But as a common feature in many species so far studied no significant antagonism between factors promoting vegetative growth and those eliciting gametogenesis seems to exist." Although this generalization was tenable in 1977, recent studies on both periphytic and planktonic taxa suggest that sexual initiation is often accomplished during poor growth periods and that two opposing strategies, termed synchronous and asynchronous, may more accurately describe the ecology of diatom sexuality. During synchronous sexuality, reproduction is limited only to short time periods and may or may not involve a large proportion of the population. Round's (1982) description of a two-week period of sexuality in Stephanodiscus exemplifies this strategy. Asynchronous sexuality is characterized by longer periods of sexual reproduction. Secondarily, these two strategies can be approached during periods of either strong or weak vegetative growth, suggesting to us that four autecologic life history strategies exist. Descriptions of and representative taxa using these four life history strategies follow.

Synchronous sexuality under favorable growth canditions. Most reports of sexuality in natural collections are from taxa that utilize this strategy. It is identified by large numbers of cells undergoing sexuality for short time periods. When many cells are in the sex- ually inducible size range and growth conditions are favorable, large numbers may enter the sexual process. This is common in spring epiphytic and epilithic masses of Cymbella and Gomphonema (Figs. 6, 7) and has been further reported in Mastogloia grevillei W. Sm. (Main 1995) and in Didymosphenia geminata (Meyer 1929) from Lake Baikal. The cue for sexual induction is probably tied to seasonal signals (light and/or temperature) that coincide with excellent vegetative growth conditions. Planktonic species may also utilize this strategy. Corethron criophilum (Crawford 1995) was seen undergoing massive sexuality in the South Atlantic for a short time, and it was suggested that the sinking of gametangial valves led to monospecific sediment layers in the seabed. Jewson (1992b) witnessed sexual reproduction in nearly $50 \%$ of the inducible cells in a population of Stephanodiscus cf. neoastrea during only 3-4 weeks in late summer and early fall during successive growing seasons. An increase in nitrate above $10 \mu \mathrm{M}$ was the sexual induction cue and also coincided with the initiation of the fall growth period for this taxon. By utilizing this strategy, diatoms are able to ensure completion of sexuality and that sexual progeny are capable of further growth.

Synchronous sexuality under poor growth conditions. When an actively growing population is suddenly checked or arrested in its development, some diatoms will undergo sexuality in response to environmental stress. This results in a portion of the population (ca. $3 \%$ in the two studies discussed) undergoing sexual reproduction over a short time period. For instance, Ditylum brightwellii (Waite and Harrison 1992) was studied in natural and cultured populations and found to initiate sexuality concurrent with nitrogen limitation. Sexuality was seen in natural populations of Ditylum on only one sampling date. Culture studies indicated that sexual induction increased the sinking rate of Ditylum, presumably a mechanism that allowed it to procure additional nitrate, which was critical to completing sexuality. Once Ditylum reached the postauxospore stage, sinking rates decreased and many cells actually became positively buoyant, allowing recolonization of surface waters. Jewson et al. (1993) reported a similar strategy by Aulacoseira herzogii (Lemmerm.) Simonsen in a hypertrophic tropical lake. Sexuality appeared to be initiated by low light conditions checking the growth of a previously asexual population. Sexual activity was evident in 3\% of the population on one September sampling date and was followed by loss of the sexual products to sedimentation, presumably to later recolonize the water column. This strategy may appear risky, because cellular reserves might not support completion of sexuality, but has apparent evolutionary value in patchy environments (Waite and Harrison 1992).

Asynchronous sexuality under favorable growth conditions. Low numbers of cells participating in sex over an extended time during normal growth periods 
characterizes a third sexual strategy. Aulacoseira baicalensis (K. I. Mey.) Simonsen (Skabitschewsky 1929) is endemic to Lake Baikal and has a period of asynchronous sexuality approximately once a year which lasts 2-3 months between the end of winter and the beginning of spring (Fig. 4). This timing coincides with the normal seasonal growth of $A$. baicalensis (Skabitschewsky 1929, Kozhov 1963). Jewson (1992a), in one of the only comprehensive biological, chemical, and physical studies of diatom life histories, observed that $A$. subarctica also utilizes asynchronous sexuality during its normal growth period in Lough Neagh, Ireland. Sexuality in $A$. subarctica is cued by sufficient nutrients (probably nitrate) and low light during the late fall and winter months. During this time, A. subarctica is actively growing, albeit slowly, with a low number of cells usually involved in sexual reproduction over the course of several months. The benthic diatom Nitzschia sigmoidea may also use this life history strategy. Mann (1988) followed size changes over the course of several years in Blackford Pond, Scotland, but was unable to observe sexual activity in $N$. sigmoidea in natural collections. However, a reappearance of large-celled populations occurred during its normal growth period (winter-spring) providing at least circumstantial evidence of asynchronous sexuality during normal growth periods. This strategy may be more common in slow-growing taxa. It minimizes risk to the whole population by allowing only a small portion to commit to sexuality at any given time, but provides conditions conducive to completion of sexuality and continued vegetative growth.

Asynchronous sexuality under poor growth conditions. The fourth sexual strategy used by diatoms is characterized by small numbers of cells going through sexuality at times when vegetative growth conditions are poor, a situation that makes this strategy the most poorly understood type. This strategy may be similar to the low levels of continuous sexuality maintained in some chrysophyte populations (Sandgren 1981). Many of the thousands of diatom taxa for which sexuality is unknown may utilize this scheme. Mizuno and Okuda (1985) provided perhaps the best example; they used cultures of Cocconeis scutellum var. ornata Grunow and found the best conditions for growth (long days, $14^{\circ}-18^{\circ} \mathrm{C}$ ) and sexuality (short days, $10^{\circ}-14^{\circ} \mathrm{C}$ ) were incongruent. When Mizuno and Okuda took their results into the field they found good agreement between culture and field conditions for strong vegetative reproduction. However, Mizuno and Okuda were only able to document sexuality by the regeneration of largesized cells. They were unable to witness sexuality, suggesting that very small numbers of cells actually participated and that it occurred during times of poor vegetative growth as predicted by their culture studies. Waite and Harrison (1992) suggested that this strategy may be advantageous in an unpredictable and constantly fluctuating environment as re- productive costs (cellular-mechanical) are minimized. Cyclotella ocellata Pant. also utilizes asynchronous sexuality during slow growth periods (PérezMartínez et al. 1992). A small proportion of a reservoir population of $C$. ocellata was continuously going through sexual reproduction between June and September during a period when this planktonic species had only maintenance-level growth. Additionally, Pérez-Martínez et al. suggested that the auxospores/initial cells acted as benthic resting stages, which may add further credence to the use of this strategy in unpredictable environments.

Continued efforts to combine studies on life history traits in field and cultured diatom populations has allowed researchers to first, identify sexual strategies in diatoms, and second, to better understand the autecologic significance of the entire diatom life history. Some of the more exciting advances in diatom life history studies have come in the area of freshwater plankton ecology. Lund's classic studies on the periodicity of phytoplankton (Aulacoseira subarctica and Asterionella formosa Hassall, Lund 1949, $1954,1955)$ corroborated studies by Nipkow (1950) on the importance of benthic resting stages in freshwater planktonic diatoms. Rather than morphologically distinct spores that are commonly found in coastal marine diatoms (McQuoid and Hobson 1996), many freshwater diatoms instead form physiologic resting cells which function to perennate diatoms through periods of stratification, ice cover, or nutrient depletion. Resting cells are cytologically and physiologically distinguishable from vegetative cells by their condensed cytoplasm and high lipid and polyphosphate content (Sicko-Goad et al. 1986). Resting cells may be incorporated in anoxic lacustrine sediments and potentially remain viable for decades, maybe even centuries (Stockner and Lund 1970, Sicko-Goad et al. 1986, 1989, Stoermer 1986). The list of freshwater taxa that incorporate this perennation strategy in their life history has grown to include many Aulacoseira, Stephanodiscus, Fragilaria, Asterionella, Tabellaria, and Diatoma species (Sicko-Goad et al. 1989), and the hypothesis that a small pelagic "seed" population survives throughout the year may not apply to most taxa. The resting cell strategy is apparently determinative in regulating the areal and temporal patterns of Aulacoseira populations in the Laurentian Great Lakes (Stoermer 1986), and we suspect it is a major factor in determining species success in many environments. One conspicuous species complex missing from the resting cell group is Cyclotella. Cyclotella spp. are known to bloom during times of turnover but perennate by remaining in the deep chlorophyll layer (Stoermer and Yang, 1969, Moll and Stoermer 1982, Fahnenstiel and Glime 1983). The importance of a benthic perennation stage in the life history of $A$. subarctica and its relation to the sexual cycle have been well documented in Lough Neagh by Jewson (1992a). Rather than a flurry of cell division from a 
small planktonic seed population creating seasonal bloom conditions, Jewson (1992a) showed that reentrainment of benthic resting cells into the water column initiated the growth period for this taxon; however, during each growing season, only six to eight cellular divisions occurred. When compared to a theoretical size diminution model as predicted by the MacDonald-Pfitzer rule, $A$. subarctica had a calculated life cycle of at least 15 years. However, environmental and cellular-mechanical size selective pressures allowed a cohort of $A$. subartica to reach sexually inducible size in only 6-8 years. The end result of this strategy was that, in Lough Neagh, a proportion of the $A$. subarctica population could participate in sexual reproduction on an annual basis, using asynchronous sexuality during its normal growth period, with the population perennating as benthic resting cells between seasonal growth pulses.

\section{Taxonomy and Diatom Life Histories}

The application of a single species concept to diatoms, in fact to most algal groups (Ichimura 1996), is very difficult. Because of a long fossil record and the predominant use of valve characters for taxonomic purposes, a morphologic species concept is most often applied to diatoms (Mann and Kociolek 1991). Although fossil studies are especially justified in using this concept, recent studies on mating compatibility within and between morphologically distinct extant taxa have suggested that a biologic species concept may be applicable to diatoms. Mann (1989c) and Droop (1994) have determined that morphologic races (usually labeled varieties) of diatoms that are often clumped into single species groups can be separated by morphometric characters, and furthermore that these races are sexually incompatible. Mann and Droop (1996) have used their evidence to champion a proposal suggesting that these morphologic races, or demes, are recognizable as separate species. This may raise the total number of recognized diatom species an order of magnitude, perhaps to as high as $2 \times 10^{5}$.

Demonstrating sexuality within a diatom population affords the investigator the opportunity to study the full size and shape range that a species may exhibit between its cardinal points (Holmes and Reimann 1966, Stoermer and Ladewski 1982, Mizuno 1987). In many diatom studies, however, populations show unimodal size distribution limited to fairly narrow ranges, probably as a result of size-selective pressures as discussed above. As a result, nomenclatural entities have been described that represent only different phases of the vegetative history of a single taxon. Kociolek and Stoermer (1988) showed that Gomphoneis herculeana and G. herculeana var. robusta (Grunow) Cleve represent a single species, the latter only the smaller end of the normal size reduction series. In a similar size reduction analysis, Holmes and Reimann (1966) determined that the centric species Coscinodiscus concinnus W. Sm. and $C$. granii are conspecific. Many of Skvortzow's Didymosphenia taxa (Skvortzow and Meyer 1928, Skvortzow 1937) are now thought to merely represent different size ranges of fewer species (Metzeltin and LangeBertalot 1995).

The initial cell ("Erstlingszelle"), which is produced immediately following sexual reproduction, can also cause taxonomic problems. This specialized cell has a modified morphology when compared to vegetative valves (Figs. 3, 6, Crawford 1975, Mann 1984b, Passy-Tolar and Lowe 1995) and can often be found in sufficient numbers to be confusing (Smith 1878, Crawford 1995). Authors have identified nomenclatural problems with species-level identifications of initial valves (Drebes 1967, Williams 1990), such as Epithemia vertagus Kütz. being the initial valve of $E$. turgida Ehrenb. (Thwaites 1847). Generic-level misnomers have also been applied to initial valves. Actinocyclus niagarae $\mathrm{H}$. L. Sm. is the initial valve of Stephanodiscus niagarae (Edlund and Stoermer 1991), and the genus Amphiraphia (Chen and Zhu 1983) was described based on initial valves of Calo neis (Mann 1989a). In addition to the benefits of recognizing the vegetative morphology of diatoms over the course of size diminution, phycologists must also understand the morphologic variation and systematic value of sexual reproduction characters (Mann 1984b).

A greater understanding of diatom life histories has resulted in the application of an organismal approach to diatom classification. For the better part of the 20th century, diatom taxonomy and systematics has been based on frustule morphology. However, two developments have radically changed our view of diatom systematics. First, the advent of transmission and scanning electron microscopy provided a more detailed view of frustular morphology and greatly improved our understanding of diatom taxonomy and structure. Second, some very insightful cytologic works at the turn of the century (e.g. Mereschkowsky 1902-1903, Heinzerling 1908), in which many generic revisions were based on cytologic features, were rediscovered. Although these concepts were essentially ignored by the phycological community between 1900 and 1980 , their relevance took on great importance as relationships among the naviculoid diatoms were more closely scrutinized (Cox 1981, 1987, Mann 1989b, Round et al. 1990). The resurrection of many "forgotten" genera followed. Multiple lines of evidence incorporating aspects of sexual reproduction, in addition to frustular and $\mathrm{cy}^{-}$ tologic features, also began to provide additional lines of evidence to support more natural classification systems. Hasle et al. (1983) erected the diatom family Cymatosiraceae within the centric diatoms, especially based on oogamous reproduction, in spite of the more obvious bilateral symmetry of the valves. The call for a more holistic view of diatom systematics was outlined in Mann's (1990) pro- 
posal for utilizing a multitude of frustular, cytologic, and sexual characters that could be used to more carefully circumscribe taxa. Mann and others have utilized this approach and provided morphologic, cytologic, and sexual lines of evidence to support resurrection or inception of many naviculoid genera including Biremis (Round et al. 1990), Craticula (Mann and Stickle 1991), Placoneis (Cox 1987, Mann and Stickle 1995), Dickieia (Mann 1994b), Fallacia (Round et al. 1990), and Sellaphora (Mann 1989b).

\section{Future Directions}

Given the known diversity of extant diatoms, the fact that we know so little about their life histories argues strongly for continued efforts toward detailed descriptive work on the sexual process in all taxa. An understanding of genetic, physiologic, and environmental control of sexuality is also deficient. For example, we have evidence of the sexual initiation factors in very few taxa (Schmid 1995), and any understanding of the controlling factors in auxospore expansion and the switch to vegetative divisions is in its infancy (Schmid 1984, Davidovich 1994, Edlund and Stoermer 1996, Round 1996). In spite of some criticism of the utility of sexuality for taxonomy and systematics (Mann 1993), there is little reason to believe that the life histories of diatoms should not reflect variation from selection and provide evidence of historical evolutionary relationships (e.g. compare with the situation in the brown algae, Bell 1997). Probably very important is the role that reproductive isolation may have as the main speciation mechanism in diatoms (Mann 1989c, Theriot 1992). The need for detailed mating studies (Roschin 1994), quantitative and molecular genetic analyses (Medlin et al. 1991, 1996a, Lewis et al. 1997), and ultrastructural studies between species complexes is obvious (Mann and Droop 1996).

The few ecologic studies that have been done have only begun to reveal the variation in strategies in freshwater and marine diatoms and their subsequent importance to the aquatic ecosystem (Jewson 1992a, Crawford 1995). More importantly, these studies have opened the door for future research by inviting workers to meld field observations with laboratory studies to test ecologic hypotheses of species succession, the determinate life span of the diatom valve, strategies for cuing and timing of sexuality, ecologic utility of resting stages, cohort analysis, and the broader relation of diatom life histories to grazers, parasites, and benthic and plankton seasonality. Complex interactions between other aquatic organisms and diatom life histories probably also exist. For example, Nagai et al. (1994) showed induction of spermatogenesis in Coscinodiscus wailesii Gran was promoted by presence of a bacterium. Furthermore, the energetic benefits and costs of sexuality and selective pressures that drive evolution of life histories have not been approached. For example, some centric diatoms have been shown to be highly skewed toward male gamete production (Waite and Harrison 1992, Schmid 1995), yet we know nothing about the realized success of fertilization using this strategy (Brawley and Johnson 1992), or the possible use of sexual pheromones by diatoms in the induction, attraction, or fertilization process (Waite and Harrison 1992)

Words that were written nearly 25 years ago still echo just as clearly today as we delve deeper into diatom life histories. Davis et al. (1973:179) wrote, "Coupled with ... laboratory experiments should be extensive field studies looking for the different sexual stages and the conditions they occur under. A large amount of taxonomic work will be required to recognize the different stages ... (but) ... the taxonomic description of every diatom species should include a description of the life cycle stages."

More information on dioecy in allogamous pennate diatoms can be found in Davidovich and Bates (1998).

Contribution 590 from the Center for Great Lakes and Aquatic Sciences was supported in part by NSF grant DEB-9521882 to E. F. Stoermer

Al-Kubaisy, K. H., Schwantes, H. O. \& Siebold, G, 1981. Cytophotometrische Untersuchungen zum Generationswechsel autotropher und heterotropher siphonaler Organismen (Vaucheria sessilis und Saprolegnia ferax). Nova Heduigia 34: $301-16$

Alberch, P., Gould, S. J., Oster, G. F. \& Wake, D. B. 1979. Size and shape in ontogeny and phylogeny, Paleobiology 5:296-317.

Armbrust, E. V. \& Chisholm, S. W. 1992. Patterns of cell size change in a marine centric diatom: variability evolving from clonal isolates. J. Phycol. 28:146-56.

Armbrust, E. V., Chisholm, S. W. \& Olson, R. J. 1990. Role of light and the cell cycle on the induction of spermatogenesis in a centric diatom. J. Phycol. 26:470-8.

Bachmann, H. 1904. Cyclotella bodanica var. lemanica O. Müller in Vierwaldstättersee und ihre Auxosporenbildung. Pring. Jahrb. Wiss. Bot. 39:106-33.

Banse, K. 1976. Rates of growth, respiration and photosynthesis of unicellular algae as related to cell size-a review. J. Phycol. 12:135-40.

Bell, G. 1997. The evolution of the life cycle of brown seaweeds. Biol. J. Linnean Soc. 60:21-38.

Bellinger, E. G. 1977. Seasonal size changes in certain diatoms and their possible significance. Br. Phycol. J. 12:233-9.

Bergon, P. 1907. Les processus de division, de rajeunissement, de la cellule et de sporulation chez le Biddulphia mobiliensis Bailey. Bull. Soc. Bot. France 54:327-58.

Bethge, H. 1925. Melosira und ihre Planktonbegleiter. In Kolkwitz, R. [Ed.] Pflanzenforschung, Heft 3. Fischer, Jena, $78 \mathrm{pp}$.

Bhattacharya, D., Medlin, L., Wainright, P. O., Ariztia, E. V., Bibeau, C., Stickel, S. K. \& Sogin, M. L. 1992. Algae containing chlorophylls $a+c$ are paraphyletic: molecular evolutionary analysis of the Chromophyta. Evolution 46:1801-17.

Booth, B. C. \& Marchant, H. J. 1987. Parmales, a new order of marine chrysophytes, with descriptions of three new genera and seven new species. $J$. Phycol. 23:245-60.

Braarud, T. 1939. Microspores in diatoms. Nature (Lond.) 143: 899

Brawley, S. H. \& Johnson, L. E. 1992. Gametogenesis, gametes and zygotes: an ecological perspective on sexual reproduction in the algae. Br. Phycol. J. 27:233-52.

Cavalier-Smith, T. \& Chao, E. E. 1996. 18S rRNA sequence of Heterosigma carterae (Raphidophyceae), and the phylogeny of heterokont algae (Ochrophyta). Phycologia 35:500-10. 
Chen, I. \& Zhu, H. 1983. Amphiraphidales, a new order of the Pennatae, Bacillariophyta. Acta Phytotaxonomica Sinica 21:44956.

Chepurnov, V. A. \& Roschin, A. M. 1995. Inbreeding influence on sexual reproduction of Achnanthes longipes Ag. (Bacillariophyta). Diatom Res. 10:21-9.

Cholnoky, B. v. 1927. Über die Auxosporenbildung von Rhoicosphenia curvata. Arch. Protistenkd. 60:8-33.

Cohn, S. A., Spurck, T. P., Pickett-Heaps, J. D. \& Edgar, L. A 1989. Perizonium and initial valve formation in the diatom Navicula cuspidata (Bacillariophyceae).J. Phycol. 25:15-26.

Cox, E. J. 1981. The use of chloroplasts and other features of the living cell in the taxonomy of naviculoid diatoms. In Ross, R. [Ed.] Proceedings of the Sixth Symposium on Recent and Fossil Diatoms. Koeltz, Koenigstein, pp. 115-33.

1987. Placoneis Mereschkowsky: the re-evaluation of a diatom genus originally characterized by its chloroplast type. Diatom Res. 2:145-57.

Crawford, R. M. 1974. The auxospore wall of the marine diatom Melosira nummuloides (Dillw,) C. Ag. and related species. $\mathrm{Br}$ Phycol. J. 9:9-20.

1975. The frustule of the initial cells of some species of the diatom genus Melosira C. Agardh. Nova Hedwigia, Beih. 53 . 37-50.

- 1981. Some considerations of size reduction in diatom cell walls. In Ross, R. [Ed.] Procerdings of the Sixth Symposium on Recent and Fossil Diatoms. Koeltz, Koenigstein, pp. 253-62.

1995. The role of sex in the sedimentation of a marine diatom bloom. Limnol. Oceanogr. 40:200-4.

Crow, J. F. 1992. An advantage of sexual reproduction in a rapidly changing environment. J. Heredity 83:169-73.

Davey, M. C. 1986 . The relationship between size, density and sinking velocity through the life cycle of Melosira granulato (Bacillariophyta) Diatom Res. 1:1-18.

Davidovich, N. A. 1994. Factors controlling the size of initial cells in diatoms. Russ. J. Plant Phys. (Fiziologiya Rastenii) 41:249-54.

Davidovich, N. A. and Bates, S. S. 1998. Sexual reproduction in the pennate diatoms Pseudo-nitzchia multiseries and $P$. psendodelicaissima (Bacillariophyceae). J. Phycol. 34:(in press).

Davis, C. O., Harrison, P. J. \& Dugdale, R. C. 1973. Continuous culture of marine diatoms under silicate limitation. I. Synchronized life cycle of Skeletonema costatum. J. Phycol. 9:17580.

Drebes, G. 1966. On the life history of the marine plankton diatom Stephanopyxis palmeriana. Helgoländer Wiss. Meeresunters. 13:101-14.

1967. Bacteriastrum solitamem Mangin, a stage in the life history of the centric diatom Bacteriastrum hyalinum. Mar. Biol. $1: 40-2$.

1972. The life history of the centric diatom Bacteriastrum hyalinum. Nova Hedwigia Beih. 39:95-110.

1974. Marines Phytoplankton. G. Thieme, Stuttgart, 186 pp. 1977. Sexuality. In Werner, D. [Ed.] The Biology of Diatoms. Blackwell Scientific, Oxford, pp. 250-83.

Droop, S. J. M. 1994. Morphological variation in Diploneis smithii and D. fusca (Bacillariophyceae). Arch. Protistenkd. 144:24970 .

Drum, R. W. 1964. Notes on Iowa diatoms. VI. Frustular aberrations in Surirella ovalis. Proc. Iowa Acad. Sci. 71:51-5.

Drum, R. W., Pankratz, J. S. \& Stoermer, E. F. 1966. Electron microscopy of diatom cells. In: Helmcke, J. G. \& Krieger, W. [Eds.] Diatomeenschalen im elektronemikroskopischen Bild, Band VI. J. Cramer Verlag, Iehre, 24 pp., plates 514-613.

Edlund, M. B. \& Stoermer, E. F. 1991. Sexual reproduction in Stephanodiscus niagarae (Bacillariophyta). J. Phycol. 27:780-93. 1993. Resting spores of the freshwater diatoms Acanthoceras and Urosolenia.J. Paleolimnol. 9:55-61.

1996. Auxospore size and expansion in diatoms. J. Phycol. 32(Suppl.):15.

Edlund, M. B., Stoermer, E. F. \& Taylor, C. M. 1996. Aulacoseira skvortzowii sp. nov. (Bacillariophyta), a poorly understood diatom from Lake Baikal, Russia. $J$. Phycol. 32:165-75.

Fahnenstiel, G. L. \& Glime, J. M. 1983. Subsurface chlorophyll maximum and associated Cyclotella pulse in Lake Superior. Int. Revue ges. Hydrobiol. 68:605-16.

Fisher, N. S, Jones, G. J. \& Nelson, D. M. 1981. Effects of copper and zinc on growth, morphology and metabolism of Asterionella japonica (Cleve). J. Exp. Mar. Biol. Ecol. 51:37-56.

Fisher, R. A. 1930. The Genetical Theory of Natural Selection. Clarendon Press, Oxford, 272 pp.

Francis, D. R. \& Edlund, M. B. 1994. Diet and habitat characteristics of Pagastiella ostansa (Diptera: Chironomidae). Bull. North Amer. Benthol. Soc. 11:188.

French III, F. W. \& Hargraves, P. E. 1985. Spore formation in the life cycles of the diatoms Chaetoceros diadema and Leptocylindrus danicus. J. Phycol. 21:477-83.

1986. Population dynamics of the spore-forming diatom Leptocylindrus danicus in Narragansett Bay, Rhode Island. $J$. Phycol. 22:411-20.

Fritsch, F. E. 1935. The Structure and Reproduction of the Algae, Vol. 1. Cambridge University Press, London, $791 \mathrm{pp.}$

Gallagher, J. C. 1983. Cell enlargement in Skeletonema costatum (Bacillariophyceae). J. Phycol. 19:539-42.

Geitler, L. 1927. Somatische Teilung, Reduktionsteilung, Copulation und Parthenogenese bei Cocconeis placentula. Arch. Protistenkd. 59:506-49.

1932. Der Formwechsel der pennaten Diatomeen (Kieselalgen). Arch. Protistenkd. 78:1-226.

1939. Gameten- und Auxosporenbildung von Synedra ulna im Verleich mit anderen pennaten Diatomeen. Planta 30:551-66.

- 1952. Oogamie, Mitose, Meiose und metagame Teilung bei der zentrischen Diatomee Cyclotella. Osterr. Bot. Z. 99:50620.

- 1973. Auxosporenbildung und Systematik bei pennaten Diatomeen und die Cytologie von Cocconeis-Sippen. Österr. Bot. Z. 122:299-321.

1980. Zellteilung und Bildung von Innenschalen bei Hantzschia amphioxys und Achnanthes coarctata. Pl. Syst. Evol. 136:275-86.

- 1984. Ergänzungen zu älteren Listen der Typen der Auxosporenbildung pennater Diatomeen. Arch. Hydrobiol. 101: $101-4$.

Gould, S. J. 1977. Ontogeny and Phylogeny. Belknap Press, Harvard University Press, Cambridge, Massachusetts, $501 \mathrm{pp}$

Grover, J. P. 1989. Influence of cell shape and size on algal competitive ability. J. Phycol. 25:402-5.

Hargraves, P. E. \& French III, F. W. 1983. Diatom resting spores: significance and strategies. In Fryxell, G. [Ed.] Survival Strat egies of the Algae. Cambridge University Press, New York, pp. 49-68.

Harwood, D. M. \& Gersonde, R. 1990. Lower Cretaceous diatoms from ODP leg 113 site 693 (Weddell Sea). Part 2: resting spores, chrysophycean cysts, an endoskeletal dinoflagellate, and notes on the origin of diatoms. Proc. Ocean Drill. Prog,, Sci. Res. 113:403-25.

Harwood, D. M. \& Nikolaev, V. A. 1996. Cretaceous diatoms: morphology, taxonomy, biostratigraphy. In Blome, C. D. et al. (conveners) Siliceous Microfossils. Paleontological Society Short Courses in Paleontology 8:81-106.

Hasle, G. R., von Stosch, H.-A. \& Syvertsen, E. E. 1983. Cymatosiraceae, a new diatom family, Bacillaria $6: 9-156$

Heath, I. B. \& Darley, W. M. 1972. Observations on the ultrastructure of the male gametes of Biddulphia laevis Ehr. J. Phycol. 8:51-9.

Heinzerling, O. 1908. Der Bau der Diatomeenzelle mit besonderer Berücksichtigung der ergastischen Gebilde und der Beziehung des Baues zur Systematik. In Luerssen, C. [Ed.] Bib inotheca Botanica, Heft 69. E. Schweizerbartsche Verlagsbuchhandlung, Stuttgart, 88 pp., 3 plates.

Holmes, R. W. \& Reimann, B. E. F. 1966 . Variation in valve morphology during the life cycle of the marine diatom Coscinodiscus concinnus. Phycologia 5:233-44.

Hoops, H. J. \& Floyd, G. L. 1979. Ultrastructure of the centric diatom, Cyclotella meneghiniana: vegetative cell and auxospore development. Phycologia 18:424-35. 
Hori, T. [Ed.] 1993. An Illustrated Atlas of the Life History of Algae. Vol. 3. Unicellutar and Flagellated Algae. Uchida Rokakuho Publishing Co., L.td., Tokyo, $313 \mathrm{pp}$.

Hostetter, H. P. \& Hoshaw, R. W. 1972. Asexual developmental patterns of the diatom Stauroneis anceps in culture. J. Phycol. 8:289-96.

Ichimura, T. 1996. Genome rearrangement and speciation in freshwater algae. Hydrobiologia 336:1-17.

Idei, M. \& Chihara, M. 1992. Successive observations on the fertilization of a centric diatom Melosira moniliformis var. octagona. Bot. Mag., Tokyo 105:649-58.

Jewson, D. H. 1992a. Life cycle of a Stephanodiscus sp. (Bacillariophyta). J. Phycol. 28:856-66.

1992b. Size reduction, reproductive strategy and the life cycle of a centric diatom. Phil. Trans. R. Soc., Lond. B 335: 191-213.

Jewson, D. H., Khondker, M., Rahman, M. H. \& Lowry, S. 1993. Auxosporulation of the freshwater diatom Aulacoseira herzogii in Lake Banani, Bangladesh. Diatom Res. 8:403-18.

Jewson, D. H. \& Lowry, S. 1993. Cymbellonitzschia diluviana Hustedt (Bacillariophyceae): habitat and auxosporulation. Hydrobiologia 269/270:87-96.

Karsten, G. 1900. Die Auxosporenbildung der Gattungen Cocconeïs, Surirella und Cymatopleura. Flora 87:253-83.

- 1912. Über die Reduktionsteilung bei der Auxosporenbildung von Surirella saxonica. Z. Bot. 4:417-26,

Klebahn, H. 1896. Beiträge zur Kenntniss der Auxosporenbildung. I. Rhopalodia gibba (Ehrenb.) O. Müller. Jahrb. Wiss. Bot. 29:595-654.

Kling, H. J. 1993. Asterionella formosa Ralfs: the process of rapid size reduction and its possible ecological significance. Diatom Res. 8:475-9.

Kociolek, J. P. \& Stoermer, E. F. 1988. Taxonomy, ultrastructure and distribution of Gomphoneis herculeana, G. eriense, and closely related species. Proc. Acad. Nat. Sci. Philadelphia 140:24-97.

1989. Phylogenetic relationships and evolutionary history of the diatom genus Gomphoneis. Phycologia 28:438-54.

Kociolek, J. P., Theriot, E. C. \& Williams, D. M. 1989. Inferring diatom phylogeny: a cladistic perspective. Diatom Res. 4:289300 .

Korshikov, A. A. 1930. On the origin of the diatoms. Beih. Bot. Centralblatt 46:460-9.

Kozhov, M. M. 1963. Lake Baikal and its Life. Dr. W. Junk Publishers, The Hague, $344 \mathrm{pp}$.

Lee, J. J. \& Xenophontes, X. 1989. The unusual life cycle of Navicula muscatinei. Diatom Res. 4:69-77.

Lewis, R. J., Jensen, S. I., DeNicola, D. M., Miller, V. I., Hoagland, K. D. \& Ernst, S. G. 1997. Genetic variation in the diatom Fragilaria capucina (Fragilariaceae) along a latitudinal gradient across North America. Pl. Syst. Evol, 204:99-108.

Lewis, W. M., Jr. 1983. Interruption of synthesis as a cost of sex in small organisms. Am. Nat. 121:825-34.

- 1984. The diatom sex clock and its evolutionary significance. Am. Nat. 123:73-80.

1987. The cost of sex. In Stearns, S. C. [Ed.] The Exolution of Sex and its Consequences. Birkhauser Verlag, Basel, Switzerland, pp. 33-57.

Locker, F. 1950. Beiträge zur Kenntnis der Formwechsels der Diatomeen an Hand von Kulturversuchen. Österr. Bot. Z. 97 322-32.

Lund, J. W. G. 1949. Studies on Asterionella, 1. The origin and nature of the cells producing seasonal maxima. J. Ecol. 37 : $389-418$.

- 1954. The seasonal cycle of the plankton diatom, Melosira italica (Ehr.) Kütz. subsp. subarctica O. Müll. J. Ecol. 42:15179.

1955. Further observations on the seasonal cycle of $M \varepsilon^{-}$ losira italica (Ehr.) Kütz. subsp. subarctica $\mathrm{O}$. Müll. J. Ecol. 43: 91-102.

MacDonald, J. D. 1869. On the structure of the diatomaceous frustule, and its genetic cycle. Ann. Mag. Nat. Hist., Ser. 4, 3 : $1-8$.

Magne-Simon, M.-F. 1962. L'auxosporulation chez une Tabellar- iacée marine, Grammatophora marina (Lyngb.) Kütz (Diatomée). Cahiers de Biologie Marine 3:79-89.

Main, S. P. 1995. Observations of auxospore production and initial cell formation in Mastogloia grevillei. In Kociolek, J. P. \& Sullivan, M. J. [Eds.] A Century of Diatom Research in North America: A Tribute to the Distinguished Careers of Charles W. Reimer and Ruth Patrick. Koeltz Scientific Books, Champaign, Illinois, pp. 79-86.

Mann, D. G. 1982. Structure, life history and systematics of Rhoi cosphenia (Bacillariophyta). II. Auxospore formation and perizonium structure of $R$ h. curvata. J. Phycol. 18:264-74.

- 1984a. Auxospore formation and development in Neidium (Bacillariophyta). Br. Phycol. J. 19:319-31.

1984b. Structure, life history and systematics of Rhoicosphenia (Bacillariophyta). V. Initial cell and size reduction in Rh. curvata and a description of the Rhoicospheniaceae fam. nov. J. Phycol. 20:544-55.

1988. Why didn't Lund see sex in Asterionella? A discussion of the diatom life cycle in nature. In Round, F. E. [Ed.] Algae and the Aquatic Environment. Biopress Ltd., Bristol, U.K., pp. 384-412.

Pp. $1989 \mathrm{a}$. On auxospore formation in Caloneis and the nature of Amphiraphia (Bacillariophyta). Pl. Syst. Evol. 163:4352.

1989b. The diatom genus Sellaphora: separation from $\mathrm{Na}$ vicula. Br. Phycol. J. 24:1-20.

- 1989c. The species concept in diatoms: evidence for morphologically distinct, sympatric gamodemes in four epipelic species. Pl. Syst. Evol. 164:215-37.

1990. Towards a revision of the raphid diatoms. In Simola, H. [Ed.] Proceedings of the Tenth International Diatom Symposium, Koeltz, Koenigstein, pp. 23-35.

1993. Patterns of sexual reproduction in diatoms. Hydrobiologia 269/270:11-20.

- 1994a. The origins of shape and form in diatoms: the interplay between morphogenetic studies and systematics. In Ingram, D. S. \& Hudson, A. J. [Eds.] Shape and Form in Plants and Fungi. Academic Press, London, pp. 17-38.

- 1994b. Auxospore formation, reproductive plasticity and cell structure in Navicula ulvacea and the resurrection of the genus Dickieia (Bacillariophyta). Eur. J. Phycol. 29:141-57.

- 1996. The systematics of Stauroneis (Bacillariophyta): sexual reproduction and auxospore development in $S$. anceps var. siberica. Nova Hedwigia, Beih. 112:307-19.

Mann, D. G. \& Droop, S. J. M. 1996. Biodiversity, biogeography and conservation of diatoms. Hydrobiologia 336:19-32.

Mann, D. G. \& Kociolek, J. P. 1991. The species concept in diatoms: report on a workshop. In Simola, H. [Ed.] Proceedings of the Tenth International Diatom Symposium, Koeltz, Koenigstein, pp. 577-83.

Mann, D. G. \& Marchant, H. J. 1989. The origins of the diatom and its life cycle. In Green, J. C., Leadbeater, B. S. C. \& Diver, W. L. [Eds.] The Chromophyte Algae: Problems and Perspectives. Systematic Association Special Volume No. 38, Claredon Press, Oxford, pp. 307-23.

Mann, D. G. \& Stickle, A. J. 1991. The genus Craticula. Diatom Res, 6:79-107.

- 1995. Sexual reproduction and systematics of Placoneis (Bacillariophyta). Phycologia 34:74-86.

Manton, I., Kowallik, K. \& von Stosch, H.-A. 1969a. Observations on the fine structure and development of the spindle at mitosis and meiosis in a marine centric diatom (Lithodesmium undulatum). I. Preliminary survey of mitosis in spermatogonia. J. Microse. 89:295-320.

1969b. Observations on the fine structure and development of the spindle at mitosis and meiosis in a marine centric diatom (Lithodesmium undulatum). II. The early meiotic stages in male gametogenesis. J. Cell. Sci. 5:271-98.

- 1970a. Observations on the fine structure and development of the spindle at mitosis and meiosis in a marine centric diatom (Lithodesmium undulatum). III. The later stages of meiosis 1 in male gametogenesis. J. Cell. Sci. 6:131-57.

$1970 \mathrm{~b}$. Observations on the fine structure and develop- 
ment of the spindle at mitosis and meiosis in a marine centric diatom (Iithodesmium undulatum). IV. The second meiotic division and conclusion. $J$. Cell. Sci. 7:407-43.

Manton, I. \& von Stosch, H.-A. 1966. Observations on the fine structure of the marine centric diatom Lithodesmium undula tum. J. Roy. Micros. Soc. 85:119-34.

Maynard Smith, J. 1978. The Evolution of Sex. Cambridge University Press, Cambridge, 222 pp.

McQuoid, M. R. \& Hobson, L. A. 1995. Importance of resting stages in diatom seasonal succession. J. Phycol. 31:44-50.

1996. Diatom resting stages. J. Phycol. 32:889-902.

Medlin, L. K., Elwood, H. J., Stickel, S. \& Sogin, M. L. 1991. Morphological and genetic variation within the diatom Skeletonema costatum (Bacillariophyta): evidence for a new species, Skeletonema pseudocostatum. J. Phycol. 27:514-24.

Medlin, L. K. \& Fryxell, G. A. 1984. Structure, life history and systematics of Rhoicosphenia (Bacillariophyta). IV. Correlation of size reduction with changes in valve morphology of $R h$. genuflexa. J. Phycol. 20:101-8.

Medlin, L. K., Kooistra, W. H. C. F., Gersonde, R., Sims, P. A. \& Wellbrock, U. 1997. Is the origin of the diatoms related to the end-Permian mass extinction? Nova Hedwigia $65: 1-11$.

Medlin, L. K., Kooistra, W. H. C. F., Gersonde, R. \& Wellbrock, U. 1996a. Evolution of the diatoms (Bacillariophyta): III. Molecular evidence for the origin of the Thalassiosirales. Nova Hedwigia, Beih. 112:221-34.

1996b. Evolution of the diatoms (Bacillariophyta): II. Nuclear-encoded small-subunit rRNA sequence comparisons confirm a paraphyletic origin for the centric diatoms. Mol. Biol. Evol. 13:67-75.

Medlin, L. K., Williams, D. M. \& Sims, P. A. 1993. The evolution of the diatoms (Bacillariophyta). I. Origin of the group and assessment of the monophyly of its major divisions. Eur. $J$ Phycol. 28:261-75.

Merechkowsky, C. 1902-1903. Le types de l'endochrome chez. les Diatomées. Scripta Botanica, Horti Universitalis Imperialis Petropolitanae 21:1-106 (in Russian); 107-93 (in French).

Metzeltin, D. \& Lange-Bertalot, H. 1995. Kritische Wertung der Taxa in Didymosphenia (Bacillariophyceae). Nova Hedwigia 60: $381-405$

Meyer, K. 1929. Uber die Auxosporenbildung bei Gomphonema geminatum. Arch. Protistenkd. 66:421-35.

Migita, S. 1967a. Morphological and ecological studies on sexual reproduction of marine centric diatoms. Inform. Bull. Planktol. Jap. 14:13-22.

- 1967b. Sexual reproduction of centric diatom Skeletonema costatum. Bull. Jap. Soc. Sri. Fish. 33:392-8.

Mizuno, M. 1987. Morphological variation of the attached diatom Cocconeis scutellum var. scutellum (Bacillariophyceae). J. Phycol. 23:591-7.

- 1991. Influence of cell volume on the growth and size reduction of marine and estuarine diatoms. $\int$. Phycol. 27: 473-8.

1994. Sexual reproduction and auxospore formation in Achnanthes javanica f. subconstricta. Diatom Res. 9:133-41.

Mizuno, M. \& Okuda, K. 1985. Seasonal change in the distribution of cell size of Corconeis sculellum var. ornata (Bacillariophyceae) in relation to growth and sexual reproduction. $J$. Phycol. 21:547-53.

Moll, R. A. \& Stoermer, E. F. 1982. A hypothesis relating trophic status and subsurface chlorophyll maxima of lakes. Arch. Hydrobiol. 94:425-40.

Murphy, L. S. 1978. Biochemical taxonomy of marine phytoplankton by electrophoresis of enzymes. II. Loss of heterozygosity in clonal cultures of the centric diatoms Skeletonema costatum and Thalassiosira pseudonana. J. Phycol. 14:247-50.

Nagai, S., Hori, Y., Manabe, T. \& Imai, I. 1994. Promotion of sperm formation of a giant diatom Coscinodiscus wailesii Gran by a marine bacterium. Fisheries $S a$. 60:625-6.

- 1995. Restoration of cell size by vegetative cell enlargement in Coscinodiscus wailesii (Bacillariophyceae). Phycologia 34:533-5.

Nakahara, H. \& Ichimura, T. 1992. Convergent evolution of ga- metangiogamy both in the zygnematalean green algae and in the pennate diatoms. Jap. J. Phycol. 40:161-6.

Nipkow, F. 1928. Über das Verhalten der Skelette planktischer Kieselalgen im geschichteten Tiefenschlamm des Zurich-und Baldeggersees. 7. Hydrol. Hydrogr. Hydrobiol. 4:71-120.

1950. Ruheformen planktischer Kieselalgen im gesichten Schlamm des Zürichsees. Schweiz Z. Hydrol. 12:263-70.

Paasche, E. 1973. Silicon and the ecology of marine plankton diatoms. I. Thalassiosira pseudonana Hasle and Heimdal ( $C_{y-}$ clotella nana Hust.) grown in a chemostat with silicate as the limiting nutrient. Mar. Biol. 19:117-26.

Parker, B. C. 1971. On the evolution of isogamy to oogamy. In Parker, B. C. \& Brown, R. M., Jr. [E.ds.] Contributions in Phycology. Allen Press, Inc., Lawrence, Kansas, pp. 47-51.

Pascher, A. 1921. Über die Übereinstimmungen zwischen den Diatomeen, Heterokonten und Chrysomonaden. Ber. Deutsch. Bot. Ges. 39:236-48.

Passy-Tolar, S. I. \& Lowe, R. L. 1995. Gomphoneis mesta (Bacillariophyta). II. Morphology of the initial frustules and perizonium ultrastructure with some inferences about diatom evolution. J. Phycol. 31:447-56.

Persidsky, B. M. 1935. The sexual process in Melosira varians. Beih. Bot. Centralbl. 53(Part A):122-32.

Pérez-Martínez, C., Cruz-Pizarro, L. \& Sánchez-Castillo, P. 1992. Auxosporulation in Cyclotella ocellata (Bacillariophyceae) under natural and experimental conditions. J. Phycol. 28:60815.

Pfitzer, E. 1869. Über den Bau und Zellteilung der Diatomeen. Bot. Z. 27:774-6.

1871. Untersuchungen über Bau und Entwicklung der Bacillariaceen (Diatomeen). In Hanstein, J. [Ed.] Botanische Abhandlungen aus dem Gebiet der Morphologie und Physiologie $1(2): 1-189$

Philippe, H., Sörhannus, U., Baroin, A., Perasso, R., Gasse, F. \& Adoutte, A. 1994. Comparison of molecular and paleontological data in diatoms suggests a major gap in the fossil record. J. Evol. Biol. 7:247-65.

Pickett-Heaps, ]., Hill, D. R. A. \& Blaze, K. L. 1991. Active gliding motility in an araphid marine diatom, Ardissonea (formerly Synedra) crystallina.J. Phycol. 27:718-25.

Rao, V. N. R. \& Desikachary, T. V. 1970. MacDonald-Pfitzer hypothesis and cell size in diatoms. Nova Hedwigia Beih. 31:48593

Reimann, B. E. F., Lewin, J. C. \& Volcani, B. E. 1966. Studies on the biochemistry and fine structure of silica shell formation in diatoms. II. The structure of the cell wall of Navicula pelliculosa (Bréb.) Hilse. J. Phycol. 2:74-84.

Reznick, D. 1992. Measuring the costs of reproduction. Trends Ecol. Evol. 7:42-5.

Richardson, J. L. 1995. Dominance of asexuality in diatom life cycles: evolutionary, ecological and taxonomic implications. In Marino, D. \& Montresor, M. [Eds.] Procedings of the Thirteenth International Diatom Symposium, Biopress Ltd., Bristol, U.K., pp. 129-37.

Roessler, P. G. 1988. Characteristics of abrupt size reduction in Synedra ulna (Bacillariophyceae). Phycologia 27:294-7.

Roshchin, A. M. 1990. Coexistence of monoecism and dioecism in Nitzschia lanceolata W. Sm. diatomaceous algae. Zhurnal ob shchej biologii, 51:699-708 (in Russian).

1994. Zhiznennye tsikly diatomovykh vodoroslei. Diatom Life Cycles. Naukova Dumka, Kiev, Ukraine, 170 pp. (in Russian)

Roshchin, A. M. and Chepurnov, V. A. 1996. Dioecy and monoecy in pennate diatoms. In I4th International Diatom Symposium, Abstracts. September 2-8, 1996, Tokyo, p. 102.

Ross, R., Cox, E. J., Karayeva, N. I., Mann, D. G., Paddock, T. B. B., Simonsen, R. \& Sims, P. A. 1979. An amended terminology for the siliceous components of the diatom cell. Nova Hedwigia, Beih. 64:513-33.

Round, F. E. 1972. The problem of reduction of cell size during diatom cell division. Nova Hedwigia 23:291-303. 1981a. Morphology and phyletic relationships of the silicified algae and the archetypal diatom-monophyly or polyphyly. In Simpson, T. L. \& Volcani, B. E. [Eds.] Silicon and 
Siliceous Structures in Biological Systems. Springer-Verlag, New York, pp. 97-128.

- 1981b. Some aspects of the origin of diatoms and their subsequent evolution. BioSystems 14:483-6.

- 1982. Auxospore structure, initial valves and the development of populations of Stephanodiscus in Farmoor Reservoir. Ann. Bot. 49:447-59.

- 1993. A Synedra (Bacillariophyta) clone after several years in culture. Nova Hedwigia, Beih. 106:353-9.

1996. Fine detail of siliceous components of diatom cells. Nova Hedwigia, Beih. 112:201-13.

Round, F. E. \& Crawford, R. M. 1981. The lines of evolution in the Bacillariophyta. I. Origin. Proc. R. Soc. Lond. (B) 211 1:23760 .

Round, F. E., Crawford, R. M. \& Mann, D. G. I990. The Diatoms: Biology and Mopphology of the Genera. Cambridge University Press, Cambridge, $747 \mathrm{pp}$.

Rozumek, K.-E. 1968. Der Einfluss der Umweltfaktoren Licht und Temperatur auf die Ausbildung der Sexualstadien bei der pennaten Diatomee Rhabdonema adriaticum Kütz. Beitr. Biol. Pflanzen 44:365-88.

Sandgren, C. D. 1981. Characteristics of sexual and asexual resting cyst (statospore) formation in Dinobryon cylindricum Imhof (Chrysophyta). J. Phycol. 17:199-210.

Saunders, R. P. 1968. Cerataulina pelagica (Cleve) Hendey. Florida Bd. Conserv. Leafl. Ser., 1 (Part 2, No. 5):1-11.

Schmid, A.-M. M. 1984. Wall morphogenesis in Thalassiosira eccentrica: comparison of auxospore formation and the effect of MT-inhibitors. In Mann, D. G. [Ed.] Proceedings of the Seventh International Diatom Symposium. Koeltz, Koeningstein, pp. $47-70$.

- 1991. Obituary. A life for cell biology-a life for diatoms. Professor Dr. Lothar Geitler. Diatom Res. 6:181-93.

1995. Sexual reproduction in Cascinodiscus granii Gough in culture: a preliminary report. In Marino, D. \& Montresor, M. [Eds.] Proceedings of the Thirteenth International Diatom Symposium, Biopress Limited, Bristol, U.K., pp. 139-59.

Schmidt, P. 1931. Die Reduktionsteilung bei der Mikrosporenbildung von Coscinodiscus apiculatus Ehrenberg und andere Ergebnisse zur Biologie dieser Diatomee. Int. Rev. ges. Hydrobiol, 25:68-101.

Schulz, P. 1929. Über Zellteilung und Dauersporenbildung der Diatomeengattungen Attheya und Rhizosolenia. Bot. Arch. 24: 505-23.

Schütt, F. 1893. Wechselbeziehungen zwischen Morphologie, Biologie, Entwicklungsgeschichte und Systematik der Diatomeen. Ber. Deutsch. Bot. Ges, 11:563-71.

Sicko-Goad, L., Stoermer, E. F. \& Fahnenstiel, G. 1986. Rejuvenation of Melosira granulata resting cells from the anoxic sediments of Douglas Lake, Michigan. I. Light microscopy and ${ }^{14} \mathrm{C}$ uptake. J. Phycol. 22:22-8.

Sicko-Goad, L., Stoermer, E. F. \& Kociolek, J. P. 1989. Diatom resting cell rejuvenation and formation: time course, species records and distribution. J. Plankton Res. 11:375-89.

Simonsen, R. 1979. The diatom system: ideas on phylogeny. $B a-$ cillaria $2: 9-71$

Skabitschewsky, A. P. 1929. Uber die Biologie von Melosira baicalensis (K. Meyer) Wisl. Russische Hydrobiologische Zeitschrift 8: 93-114. (in Russian)

Skvortzow, B. W. 1937. Bottom diatoms from Olhon Gate of Baikal Lake, Siberia. Philipp. J. Sci. 62:293-377.

Skwortzow, B. W. \& Meyer, C. I. 1928. A contribution to the diatoms of Baikal Lake. Proc. Sungaree River Biol. Sin. 1 (5):1-55.

Small, J. 1945. Tables to illustrate the geological history of species number in diatoms. Proc. R. Irish Acad., Sect. B. 50:295309.

Smith, H. L. 1878. Description of new species of diatoms. Am. Quart. Mirr. J. 1:12-18.

Sorhannus, U., Gasse, F., Perasso, R. \& Tourancheau, A. B. 1995. A preliminary phylogeny of diatoms based on $28 \mathrm{~S}$ ribosomal RNA sequence data. Phycologia 34:65-73.

Stearns, S. C. 1989. Trade-offs in life-history evolution. Functional Ecol. 3:259-68.
Stebbins, G. L. 1969. Comments on the search for a 'perfect system'. Taxon. 18:357-9.

Stickle, A. J. 1986. Mastogloia smithii has a method of sexual reproduction hitherto unknown in raphid diatoms. Diatom Res. 1:271-82.

Stockner, J. G. \& Lund, J. W. G. 1970, Live algae in postglacial lake deposits. Limnol. Oceanogr. 15:41-58.

Stoermer, E. F. 1986. Some perspectives on diatom ecology. In Ricard, M. [Ed.] Proceedings of the Eighth International Diatom Symposium, Koeltz, Koenigstein, pp. 315-22.

Stoermer, E. F., Emmert, G. \& Schelske, C. L. 1989. Morphological variation of Stephanodiscus niagarae Ehrenb. (Bacillariophyta) in a Lake Ontario sediment core. J. Paleolimnol. 2:22736.

Stoermer, E. F. \& Ladewski, T. B. 1982. Quantitative analysis of shape variation in type and modern populations of Gomphoneis herculeana. Nova Hedwigia, Beih. 73:347-86.

Stoermer, E. F., Pankratz, H. S. \& Bowen, C. C. 1965. Fine structure of the diatom Amphipleura pellucida. II. Cytoplasmic fine structure and frustule formation. Amer. J. Bot. 52:1067-78.

Stoermer, E. F. \& Yang, J. J. 1969. Plankton diatom assemblages in Lake Michigan. Great Lakes Research Division Special Rep. No. 47, University of Michigan, Ann Arbor, $168 \mathrm{pp}$.

Subramanyan, R. 1946. On the occurrence of microspores in some centric diatoms of the Madras coast. J. Indian Bot. Soc. 25:61-6.

Tappan, H. 1980. The Paleobiology of Plant Protists. W. H. Freeman and Co., San Francisco, 1028 pp.

Taylor, N. J. 1985. Silica incorporation in the diatom Coscinodiscus granii as affected by light intensity. Br. Phycol. J. 20:36574.

Theriot, E. 1989. Phylogenetic systematics for phycology. /. Phycol. 25:407-11.

1992. Clusters, species concepts, and morphological evolution of diatoms. Syst. Biol. 41:141-57.

Theriot, E. \& Serieyssol, K. 1994. Phylogenetic systematics as a guide to understanding features and potential morphological characters of the centric diatom family Thalassiosiraceae. Diatom Res. 9:429-50.

Thwaites, G. H. K. 1847. On conjugation in the Diatomaceae. Ann. Mag. Nat. Hist. 20:343-4.

- 1848. Further observations on the Diatomaceae; with descriptions of new genera and species. Ann. Mag. Nat. Hist. Ser. 2, 1:161-72.

Tschermak-Woess, E. 1973. Über die bisher vergeblich gesuchte Auxosporenbildung von Diatoma. Österr. Bot. Z, 121:23-7.

van den Hoek, C., Mann, D. G. \& Jahns, H. M. 1995. Algae: An Introduction to Phycology. Cambridge University Press, Cambridge, $623 \mathrm{pp}$.

Vaulot, D. \& Chisholm, S. W. 1987. Flow cytometric analysis of spermatogenesis in the diatom Thalassiosira weissflogii (Bacillariophyceae). J. Phycol. 23:132-7.

von Stosch, H.A. 1950. Oogamy in a centric diatom. Nature (Lond.) 165:531-2.

1958. Kann die oogame Araphidee Rhabdonema adriaticum als Bindeglied zwischen den beiden grossen Diatomeengruppen angesehen werden? Ber. Deutseh. Bot. Ges. 71:241-9.

1962. Über das Perizonium der Diatomeen. Vorträgen aus dem Gesamtgehiet der Botanik 1:43-52.

- 1965. Manipulierung der Zellgrösse von Diatomeen im Experiment. Phycologia 5:21-44.

1967. Diatomeen. In Ettl, H., Müller, D. G., Neumann, K., von Stosch, H.A. \& Weber, W. [Eds.] Vegetative Fortpflanzung, Parthenogenese und Apogamie bei Algen. In Ruhland, W. [Ed.] Handbuch der Pflanzenphysiologie, SpringerVerlag, Berlin 18:657-81.

1982. On auxospore envelopes in diatoms. Bacillaria 5 : $127-56$

von Stosch, H.-A. \& Fecher, K. 1979. "Internal thecae" of Eunotia soleirolii (Bacillariophyceae): development, structure and function of resting spores. J. Phycol. 15:233-43.

von Stosch, H.-A. Theil, G. \& Kowallik, K. V. 1973. Entwicklungsgeschichtliche Untersuchungen an zentrischen Diatomeen. 
V. Bau und Lebenszyklus von Chaetoceros didymum, mit Beobachtungen über einige andere Arten der Gattung. Helgoländer Wiss. Meeresunters. 25:384-445.

Waite, A. \& Harrison, P. J. 1992. Role of sinking and ascent during sexual reproduction in the marine diatom Ditylum brightwellii. Mar. Ecol. Prog. Ser. 87:113-22.

Werner, D. 1971. Der Entwicklungscyclus mit Sexualphase bei der marinen Diatomee Coscinodiscus asteromphalus. II. Oberflächenabhängige Differenzierung während der vegetativen Zellverkleinerung. III. Differenzierung und Spermatogenese. Arch. Mikrobiol. 80:115-46.

Wiedling, S. 1948. Beitrage zur Kenntis der vegetativen Vermehrung der Diatomeen. Bot. Not. 1948:322-54.

Wiese, L. 1968. Algae, In Metz, C. B. \& Monroy, A. [Eds.] Fertilization: Comparatize Morphology, Biochemistry, and Immunology, Vol. II. Academic Press, New York, pp. 135-85.
Williams, D. M. 1990. Examination of auxospore valves in Tetracyclus from fossil specimens and the establishment of their identity. Diatom Res. 5:189-94.

- 1991. Phylogenetic relationships among the Chromista: a review and preliminary analysis. Cladistics 7:141-56.

1994. Ontogeny and phylogeny in the genus Tetracyclus. In Kociolek, J. P. [Ed.] Proceedings of the Eleventh International Diatom Symposium, Memoirs of the California Academy of Sciences, Number 17, California Academy of Sciences, San Francisco, pp. $247-56$.

pp. 1996. Fossil species of the diatom genus Tetrayclus (Bacillariophyta, 'ellipticus' species group): morphology, interrelationships and the relevance of ontogeny. Phil. Trans. R. Soc. Lond. (B) 351:1759-82.

Williams, R. B. 1964. Division rates of salt marsh diatoms in relation to salinity and cell size. Ecology 45:877-80. 